\title{
CEO Turnover-Performance Sensitivity in Private Firms
}

\author{
Huasheng Gao, Jarrad Harford, and Kai Li*
}

\begin{abstract}
We compare chief executive officer (CEO) turnover in public and large private firms. Public firms have higher turnover rates and exhibit greater turnover-performance sensitivity (TPS) than private firms. When we control for pre-turnover performance, performance improvements are greater for private firms than for public firms. We investigate whether these differences are due to differences in quality of accounting information, the $\mathrm{CEO}$ candidate pool, CEO power, board structure, ownership structure, investor horizon, or certain unobservable differences between public and private firms. One factor contributing to public firms' higher turnover rates and greater TPS appears to be investor myopia.
\end{abstract}

\section{Introduction}

Hiring and firing a chief executive officer (CEO) may be the most important job of a corporate board. Starting from the studies of Coughlan and Schmidt (1985), Warner, Watts, and Wruck (1988), and Weisbach (1988), there is a large literature in finance and accounting examining how CEO turnover takes place. As a testament to its importance, the topic continues to attract considerable interest, including recent work by Taylor (2010), Fisman, Khurana, Rhodes-Kropf,

\footnotetext{
*Gao, hsgao@ntu.edu.sg, Nanyang Business School, Nanyang Technological University; Harford, jarrad@uw.edu, Foster School of Business, University of Washington; and Li (corresponding author), kai.li@sauder.ubc.ca, Sauder School of Business, University of British Columbia. We are grateful for helpful comments from an anonymous referee, Matt Billett, Stephen Brown (the editor), Jess Cornaggia, Andrew Ellul, Vivian Fang, Murray Frank, Ruoran Gao, Inmoo Lee, Katharina Lewellen, Rik Sen, Xuan Tian, Margarita Tsoutsoura, Andy Winton, Ting Xu, and Shan Zhao; seminar participants at the Chinese University of Hong Kong, Copenhagen Business School, Erasmus University, Indiana University, Nanyang Technological University, Shanghai Advanced Institute of Finance, the University of Amsterdam, the University of Hawaii, the University of Hong Kong, the University of Minnesota, and Vienna University of Economics and Business; and conference participants at the 2013 Annual Academic Conference on Corporate Governance (Philadelphia), the 2013 London Business School Summer Corporate Finance Symposium (London), the 2013 China International Conference in Finance (Shanghai), the 2013 Northern Finance Association Meetings (Quebec City), and the 2014 Inaugural Edinburgh Corporate Finance Conference (Edinburgh). We also thank Yong Bao Kwang and Chu Chen for excellent research assistance. We acknowledge financial support from the Social Sciences and Humanities Research Council of Canada. All errors are ours.
} 
and Yim (2014), and Jenter and Kanaan (2015). Although we have increased our understanding of the performance and governance factors that influence CEO turnover, almost all of the evidence comes from examining public firms. ${ }^{1}$ Examining private firms offers several avenues for further insight. In addition to representing a large part of the economy, private firms differ from public firms on several important dimensions, allowing us to vary hypothesized influences far more than would be possible in public-only samples. Absent frictions and other differences, turnover frequency and performance sensitivity would be the same across the two groups. Thus, by comparing the two and exploring the differences between public and private firms, we are able not only to provide results on private-firm CEO turnover but also to deliver insights into the factors determining CEO turnover in general, including that in public firms.

In this paper, we analyze a sample of public firms and compare their CEO turnover rates and turnover-performance sensitivity (TPS) to those of a sample of large private firms. Using our combined sample of public and private firms involved in over 4,000 CEO turnover cases during the period 2001-2011, we show that public-firm CEOs are significantly more likely to experience turnover and have greater TPS compared with their private-firm counterparts.

Given the well-documented concern about public-firm CEO entrenchment, it may at first seem surprising that public-firm CEOs are actually more likely than private-firm CEOs to be fired. However, there are many differences between public and private firms that could explain this. We account for the possibility that accounting performance measures are noisier for private firms. ${ }^{2}$ Further, public firms are more informationally transparent and have more media and analyst coverage, and thus public firm performance may be more informative of CEO quality and effort. This could lead to greater observed sensitivity of turnover to performance for public-firm CEOs. We also account for potential differences in the candidate pool for public- and private-firm CEOs that might lead to differential costs associated with turnover. In further investigation, we examine whether governance differences and CEO characteristics (such as founder status) explain the different turnover rates and sensitivities. Finally, public-firm investor myopia of the kind discussed by Stein (1989) could lead to differential turnover rates and TPS if public-firm investors and boards overreact to short-term underperformance. Some suggestive evidence for this difference between public and private firms is given in a recent paper by Asker, Farre-Mensa, and Ljungqvist (2015), who argue that private firms have much less pressure to invest myopically. Yet, the differences in turnover behavior persist when we introduce measures of quality of accounting information, the CEO candidate pool, CEO power, board structure, and ownership structure, as well as when we employ matched-sample analysis.

\footnotetext{
${ }^{1}$ Two contemporaneous papers, those by Lel, Miller, and Reisel (2014) and Cornelli and Karakaş (2015), examine CEO turnover in European private firms and firms taken private in leveraged buyout (LBO) transactions, respectively. A 2003 working paper by Coles, Lemmon, and Naveen studies the Forbes 1994 list and finds no differences in turnover-performance sensitivity among public- and private-firm CEOs in that group.

${ }^{2}$ Our sample contains large private firms with audited financial statements, which makes them as comparable to public firms as possible.
} 
We turn next to investor horizon using measures of short-term investors developed by Bushee (1998). We show that there are significant differences in CEO turnover rate and TPS between public firms with more short-term investors and public firms with fewer short-term investors. That is, we find that within public firms, as we go from fewer to more short-term investors, we get higher CEO turnover rates and increased sensitivity of turnover to performance. This provides some evidence supporting the role of investor myopia in explaining the differences in CEO turnover between public and private firms.

Although the evidence on investor horizon is suggestive that short-termism affects public-firm CEO turnover, the turnover could still be optimal within the constraints of being a public firm. To provide a final piece of evidence, we examine performance improvements following CEO turnover. We show that the performance of private firms improves more than that of public firms following CEO turnover, matching on prior performance. Although the results are certainly not conclusive, they suggest that private-firm CEO turnover decisions are not suboptimally slow and are instead consistent with the evidence that the short-term investor horizon associated with the public equity market can result in suboptimally quick CEO turnover in public firms. This interpretation is further bolstered by subsequent tests showing that performance improvements following CEO turnover in public firms with short-term investors are smaller than those in public firms with more long-term oriented investors.

As with any study that compares two groups, we are concerned with omitted variables related to the decision to be public that could also drive the differences we observe. Although we have tried to carefully explore the implications of the differences between public and private firms for CEO TPS, there may be some other factors we have not considered. We try to mitigate this concern by instrumenting for the public versus private status of a firm and show that our results continue to hold. Our instrumental variable is the state-level household stock market participation rate, which captures the presence of local public firms in the early 1980s but is unlikely to be related to a particular public firm's CEO turnover decision 20 years later.

Our paper contributes to two strands of the literature. First, our paper contributes to the growing literature that examines corporate policies in private firms, which account for a greater part of the U.S. economy than public firms. Due mainly to data limitations, the existing literature provides few insights into CEO turnover in private firms. This lack of evidence makes it difficult to fully understand the incentive mechanisms for top managers in the United States. Our study fills a gap in the literature by providing new evidence on private-firm CEO turnover decisions. Second, our paper sheds light on a potential source of managerial myopia in public firms (Stein (1988), (1989)). We show that the threat of turnover due to excess emphasis by public-firm shareholders and hence boards on short-term performance contributes to the observed managerial myopia in corporate investment decisions (see, e.g., Bushee (1998), Gao, Harford, and Li (2013), and Asker et al. (2015)). 


\section{Literature Review and Public-Private Firm Differences}

\section{A. Related Literature}

Coughlan and Schmidt (1985) and Warner et al. (1988) are the first in the literature to show empirically that corporate boards control top-management behavior by making compensation and management termination decisions related to the firm's stock price performance. Weisbach (1988) and Denis, Denis, and Sarin (1997), among others, have further shown that governance significantly affects the turnover-performance relation.

Parrino (1997) is one of the first to differentiate between forced versus voluntary CEO turnover and between internal and external hires. He shows that industry characteristics and their implications for the replacement pool are important for understanding turnover decisions.

Our paper is most closely related to the following papers. Coles, Lemmon, and Naveen (2003) compare profitability and CEO TPS between large public and private firms in the Forbes 1994 list. They find that although private firms on the Forbes list are less profitable than public firms, there is no difference in CEO TPS between the two groups of firms. The differences in sample coverage, sample period, and model specification potentially contribute to the difference in findings between Coles et al. (2003) and our paper. ${ }^{3}$ Based on a sample of private firms in transition economies in Central and Eastern Europe and Central Asia, Cornelli, Kominek, and Ljungqvist (2013) show that in private firms, soft information (e.g., subjective evaluation) plays a much larger role than hard information (e.g., accounting performance) in boards' decisions to fire CEOs. Lel et al. (2014) examine CEO turnover in European firms and find that public firms are significantly more likely to replace poorly performing top managers than private firms. They conclude that agency problems in public firms may be less severe than previously anticipated and that public equity markets play an important governance role. Cornelli and Karakaş (2015) examine CEO turnover in LBOs backed by private equity funds in the United Kingdom and find that when a firm is taken private, both CEO turnover and its sensitivity to performance decrease. They conclude that effective monitoring and more inside information allow these private equity funds to rely less on short-term performance and to therefore give CEOs longer horizons. Whereas Cornelli and Karakaş (2015) focus on one particular type of private firm in the United Kingdom (the ones that go private via LBOs), our study is based on a sample of large U.S. private firms (that are not LBO target firms). The two papers complement each other in examining the role of investor horizon

\footnotetext{
${ }^{3}$ Coles et al. (2003) focus on a smaller sample of public and private firms (all part of the Forbes 1994 list, resulting in 351 private firms and 766 public firms) over the period 1993-1997. Our sample comprises 5,342 public firms and 2,300 private firms over the period 2001-2011. Since 2001 after the Sarbanes-Oxley Act of 2002 (when our sample period starts), the corporate governance environment for public firms in the United States has drastically changed, with heightened emphasis on corporate governance, possibly leading to greater CEO TPS in public firms. In univariate statistics, Coles et al. (2003) also find that there is a higher CEO turnover rate in public firms compared with private firms. Further, Coles et al. use either operating profit or net profit normalized by sales, whereas we use return on assets (ROA) and sales growth to measure performance in the main model specification for CEO turnover. We also include more firm and CEO characteristics as control variables.
} 
in CEO turnover decisions, but their respective sample firms involve investors of differing horizons (private equity sponsors have shorter horizons on average than other private-firm shareholders).

\section{B. Differences between Public and Private Firms}

Private firms tend to be more closely held than are public firms, and the concentrated illiquid ownership structure provides strong shareholder monitoring (Bhide (1993), Kahn and Winton (1998), and Asker et al. (2015)). Given the greater ownership dispersion and likely more severe agency problems in public firms, one can argue that public-firm CEOs' entrenchment leads them to face a lower chance of dismissal in the face of poor performance.

At the same time, this dispersion of shareholdings and liquidity provided by the public equity market can come at the cost of shorter investment horizons. Stein (1988), (1989) describes a theory of myopia and an explanation for why public firm investors might be myopic (i.e., put more weight on current versus future earnings when valuing a firm compared with private-firm investors). Under these circumstances, CEOs who face a takeover (with dismissal) threat when the market underprices the firm would behave myopically. Bushee (1998) provides empirical evidence of myopic managerial decisions in the presence of transient investors. Assuming that corporate directors have similar career concern as CEOs following a takeover (Harford (2003)), directors would be similarly averse to short-term performance downturns and the threat of a takeover. Parrino, Sias, and Starks (2003) examine whether institutional investors "vote with their feet" when there is a performance decline and find that the presence of transient investors exacerbates any short-term performance decline. The ideas behind Stein's theory could be extended to show that even fully informed public-firm boards could choose to signal a change in strategy by myopically firing a CEO when facing a takeoverdriven loss of valuable board seats. In contrast, private-firm boards and managers can afford to take a long-term view, knowing that they will not be penalized for poor short-term performance. Given this and the evidence that transient investors exacerbate short-term performance declines, we predict that CEO turnover is more sensitive to short-term performance when there are more transient investors.

Further, direct monitoring incentives are stronger in private firms because of the more concentrated ownership and smaller boards. Ke, Petroni, and Safieddine (1999) and Gao and Li (2015) provide evidence of a substitution between direct monitoring and the use of explicit performance measures in private-firm CEO compensation design.

Examining these differences is complicated by the fact that differences in information environments and costs of executive turnover can lead to observed differences in TPS. Public-firm boards can observe both stock price and accounting performance, decreasing the weight they would put on accounting performance. On the other hand, with more media and analyst scrutiny, public firm performance measures may be more informative of CEO quality and effort, leading public-firm turnover to be more sensitive to performance. Further, if one group of firms views the cost of replacing the CEO as lower (e.g., they have a larger pool of high-quality replacements), the turnover frequency and TPS would reflect this difference. 
These differences and their effects on something as important as CEO turnover are interesting in their own right, and addressing them in our empirical tests is critical for assessing the net effect, if there is one, of being public on CEO turnover rates and TPS.

\section{Sample Formation and Overview}

We start with all U.S. public and private firms with nonmissing values for total assets in Capital IQ, an affiliate of Standard \& Poor's, from 2001 to $2011 .{ }^{4}$ We start our sample in 2001 because it is the year in which Capital IQ starts to provide detailed information on CEO turnover, such as why a CEO is replaced, who the new CEO is, and what the new CEO's background is. Public firms in our sample are those traded on the New York Stock Exchange (NYSE), American Stock Exchange (AMEX), or NASDAQ. Private firms are those without shares being traded on any major stock exchanges. (Firms traded on the over-the-counter market or nonmajor stock exchanges are excluded from our sample.)

To form our sample, we remove all firm-year observations associated with initial public offerings (IPOs) (5,829 firm-year observations) or going-private transactions (396 firm-year observations). ${ }^{5}$ We further require sample CEOs to have a minimum tenure of 2 years (losing 1,144 public firm-year observations and 1,264 private firm-year observations) so that we are not picking up the interim CEO appointments. In the end, we have 39,601 public firm-year observations involving 3,815 CEO turnover cases and 6,164 private firm-year observations involving 490 CEO turnover cases from 2001-2011. By way of comparison, Jenter and Kanaan (2015) have 16,865 firm-year observations from 1993-2001, whereas we have a total of 45,765 firm-year observations, including $13.5 \%$ of the overall sample from private firms.

Table 1 presents the annual frequency of CEO turnover in our sample of public and private firms. We show that both public and private firms experience increasingly more CEO turnover cases over the sample period, with private-firm CEO turnover peaking in the 2008-2010 financial crisis period. This finding is consistent with Campello, Graham, and Harvey (2010), who show that financially constrained firms (in our case, private firms) are more negatively impacted by the most recent crisis than unconstrained firms (in our case, public firms). Further, it is clear that public-firm CEOs, on average, experience a higher likelihood of

\footnotetext{
${ }^{4}$ Capital IQ has information on CEO turnover and financials for a large number of private firms in the United States because of the following mandatory disclosure requirements by the U.S. Securities and Exchange Commission (SEC). First, if a company decides on a registered public offering, the Securities Act of 1933 requires it to file a registration statement (Form S-1) with the SEC that contains information on executive compensation. Second, and more applicable to our sample of private firms, even if a company has not registered a securities offering, it must file an Exchange Act registration statement if it has more than $\$ 10$ million in total assets and a class of equity securities, such as common stock, with 500 or more shareholders. After that, the company is required to continue reporting via annual and quarterly reports and proxy statements. Data for a vast majority (about 90\%) of the private firm-year observations in our sample come from Form 10-K; the remainder come from Form S-1 due to public debt issuance.

${ }^{5}$ It is common for firms to change their management teams after IPOs (Kaplan, Sensoy, and Strömberg (2009)). Thus, by removing these transition firms, we can rule out the possibility that our results of more frequent CEO turnover in public firms are driven by the IPO event.
} 
TABLE 1

\section{CEO Turnover over Time}

Table 1 presents the annual frequency of CEO turnover in both public and private firms. Our sample consists of 39,601 public firm-year observations involving 3,815 CEO turnover cases, and 6,164 private firm-year observations involving 490 CEO turnover cases from 2001-2011, obtained from Capital IQ. To form our sample, we remove all firm-year observations associated with IPOs or going-private transactions. We further require sample CEOs to have a minimum tenure of 2 years.

\begin{tabular}{|c|c|c|c|c|c|c|}
\hline \multirow[b]{2}{*}{ Year } & \multicolumn{3}{|c|}{ Panel A. Public Firms } & \multicolumn{3}{|c|}{ Panel B. Private Firms } \\
\hline & $\begin{array}{l}\text { No. of } \\
\text { Firms }\end{array}$ & $\begin{array}{l}\text { No. of CEO } \\
\text { Turnovers }\end{array}$ & $\begin{array}{l}\text { \% of Firms with } \\
\text { CEO Turnover }\end{array}$ & $\begin{array}{l}\text { No. of } \\
\text { Firms }\end{array}$ & $\begin{array}{l}\text { No. of CEO } \\
\text { Turnovers }\end{array}$ & $\begin{array}{l}\text { \% of Firms with } \\
\text { CEO Turnover }\end{array}$ \\
\hline 2001 & 3,554 & 212 & $5.97 \%$ & 569 & 21 & $3.69 \%$ \\
\hline 2002 & 3,810 & 236 & $6.19 \%$ & 660 & 29 & $4.39 \%$ \\
\hline 2003 & 3,886 & 304 & $7.82 \%$ & 748 & 43 & $5.75 \%$ \\
\hline 2004 & 3,870 & 435 & $11.24 \%$ & 662 & 47 & $7.10 \%$ \\
\hline 2005 & 3,753 & 440 & $11.72 \%$ & 609 & 63 & $10.35 \%$ \\
\hline 2006 & 3,652 & 448 & $12.27 \%$ & 563 & 54 & $9.59 \%$ \\
\hline 2007 & 3,572 & 388 & $10.86 \%$ & 520 & 49 & $9.42 \%$ \\
\hline 2008 & 3,462 & 342 & $9.88 \%$ & 438 & 52 & $11.87 \%$ \\
\hline 2009 & 3,413 & 333 & $9.76 \%$ & 480 & 44 & $9.17 \%$ \\
\hline 2010 & 3,347 & 341 & $10.19 \%$ & 495 & 55 & $11.11 \%$ \\
\hline 2011 & 3,282 & 336 & $10.24 \%$ & 420 & 33 & $7.86 \%$ \\
\hline All & 39,601 & 3,815 & $9.63 \%$ & 6,164 & 490 & $7.94 \%$ \\
\hline
\end{tabular}

turnover at $9.6 \%$ per annum as compared with private-firm CEOs at $7.9 \%$ per annum.

Table 2 presents descriptive statistics for our sample. All dollar values are in 2011 dollars. All continuous variables are winsorized at the 1st and 99th percentiles. Variable definitions are provided in the Appendix.

The mean (median) total assets is $\$ 4,807$ million ( $\$ 685$ million) for the public-firm sample, and the mean (median) total assets is $\$ 2,969$ million ( $\$ 327$ million) for the private-firm sample. It is worth noting that the private firms in our sample are fairly comparable to the public firms in terms of size. However, we show that public firms have better operating performance, higher (median) sales growth, significantly lower leverage, and smaller accruals; hire more employees; are older; and have significantly more peer firms in the same industry and more other public firms in the same state.

Turning to the CEO characteristics, we show that public-firm CEOs are actually more likely to be founders. This is consistent with the fact that we are studying larger, older private firms rather than startups. Their ownership differs: Public-firm CEOs own on average $4.05 \%$ (median at $0.50 \%$ ) of their companies, as opposed to $10.74 \%$ (median at $1.50 \%$ ) for private-firm CEOs. The mean (median) age for public-firm CEOs is 56 (55) years old, and the mean (median) age for private firm CEOs is 53 (54) years old. The mean (median) tenure for public-firm CEOs is 9.04 (7) years, and the mean (median) tenure for private-firm CEOs is 7.36 (5) years. Public-firm CEOs are paid more than private-firm CEOs; the mean annual total compensation for public-firm CEOs is $\$ 3.07$ million (median at $\$ 1.39$ million), as opposed to $\$ 1.48$ million (median at $\$ 0.58$ million) for private-firm CEOs. ${ }^{6}$ In

\footnotetext{
${ }^{6}$ The annual compensation consists of salary, bonuses, restricted stock, stock options, and other compensation. The valuation of restricted stock and option grants follows Gao and Li (2015). For restricted stock in both public and private firms, we take the value as reported by the firm. For stock options in public firms, we calculate the dollar value based on ExecuComp's modified Black-Scholes (1973) approach. For stock options in private firms, we apply the Black-Scholes approach under the following assumptions: i) the volatility is the 60 -month return volatility of a public firm in the same
} 
TABLE 2

\section{Summary Statistics}

Table 2 presents a comparison of the main samples. Our sample consists of 39,601 public firm-year observations involving 3,815 CEO turnover cases and 6,164 private firm-year observations involving 490 CEO turnover cases from 2001-2011, obtained from Capital IQ. Definitions of all variables are provided in the Appendix. All dollar values are in 2011 dollars. All continuous variables are winsorized at the 1st and 99th percentiles. The last two columns present the tests of differences in means and medians between public and private firms. ${ }^{* *}$ and ${ }^{* * *}$ indicate significance at the $5 \%$ and $1 \%$ levels, respectively.

Panel A. Public Firms

\begin{tabular}{|c|c|c|}
\hline$N$ & Mean & Median \\
\hline 1 & 2 & 3 \\
\hline 39,601 & 2,379 & 313 \\
\hline 39,601 & 4,807 & 685 \\
\hline 39,601 & $4.31 \%$ & $5.22 \%$ \\
\hline 39,601 & $4.02 \%$ & $5.17 \%$ \\
\hline 39,601 & $10.13 \%$ & $10.54 \%$ \\
\hline 39,601 & $12.29 \%$ & $7.74 \%$ \\
\hline 39,601 & $12.87 \%$ & $7.99 \%$ \\
\hline 39,601 & $29.15 \%$ & $15.67 \%$ \\
\hline 39,601 & $2.66 \%$ & $1.83 \%$ \\
\hline 39,601 & $25.14 \%$ & $20.87 \%$ \\
\hline 39,601 & $5.84 \%$ & $3.57 \%$ \\
\hline 39,601 & 45 & 29 \\
\hline 39,601 & 7,072 & 975 \\
\hline 39,601 & 198 & 129 \\
\hline 39,601 & 212 & 152 \\
\hline 39,601 & 0.11 & 0.00 \\
\hline 39,601 & $4.05 \%$ & $0.50 \%$ \\
\hline 39,601 & 55.58 & 55 \\
\hline 39,601 & 9.04 & 7 \\
\hline 39,601 & 3,073 & 1,388 \\
\hline 27,903 & $80.53 \%$ & $83.34 \%$ \\
\hline 28,351 & $18.09 \%$ & $14.30 \%$ \\
\hline
\end{tabular}

Panel B. Private Firms

\begin{tabular}{c} 
Std. \\
Dev. \\
4 \\
\hline 6,516 \\
14,697 \\
$13.76 \%$ \\
$14.81 \%$ \\
$26.07 \%$ \\
$34.00 \%$ \\
$33.43 \%$ \\
$66.46 \%$ \\
$2.84 \%$ \\
$20.34 \%$ \\
$7.35 \%$ \\
38 \\
18,331 \\
164 \\
181 \\
0.31 \\
$9.22 \%$ \\
8.06 \\
7.67 \\
4,389 \\
$11.39 \%$ \\
$17.27 \%$
\end{tabular}

\begin{tabular}{c}
\hline \\
\hline \\
5 \\
\hline 6,164 \\
6,164 \\
6,164 \\
6,164 \\
6,164 \\
6,164 \\
6,164 \\
6,164 \\
6,164 \\
6,164 \\
6,164 \\
6,164 \\
6,164 \\
6,164 \\
6,164 \\
6,164 \\
6,164 \\
6,164 \\
6,164 \\
6,164 \\
4,186 \\
4,187
\end{tabular}

\begin{tabular}{l}
\multicolumn{1}{c}{ Variables } \\
\hline SALES (\$millions) \\
TOTAL ASSETS (\$millions) \\
CONTEMPORANEOUS_ROA \\
LAGGED_ROA \\
ROA \\
CONTEMPORANEOUS_SALES_GROWTH \\
LAGGED_SALES_GROWTH \\
SALES_GROWTH \\
CF_VOLATILITY \\
LEVERAGE \\
ACCRUAL \\
FIRM_AGE \\
NUMBER_OF_EMPLOYEES \\
NUMBER_OF_FIRMS_IN_THE_INDUSTRY \\
NUMBER_OF_FIRMS_IN_THE_STATE \\
FOUNDER \\
CEO_OWNERSHIP \\
CEO_AGE \\
CEO_TENURE \\
CEO_PAY (\$K) \\
BOARD_INDEPENDENCE \\
TOP5_OWNERSHIP
\end{tabular}

$\begin{array}{ccc} & & \\ \text { Mean } & & \text { Median } \\ & & 7 \\ 949 & & 185 \\ 2,969 & & 327 \\ 1.61 \% & & 4.06 \% \\ 1.97 \% & & 4.08 \% \\ 6.09 \% & & 8.48 \% \\ 14.98 \% & & 5.46 \% \\ 15.76 \% & & 5.76 \% \\ 38.43 \% & & 11.44 \% \\ 3.38 \% & & 1.76 \% \\ 48.08 \% & & 47.67 \% \\ 9.46 \% & & 4.96 \% \\ 28 & & 11 \\ 2,743 & & 459 \\ 31 & 23 \\ 28 & & 20 \\ 0.09 & & 0.00 \\ 10.74 \% & & 1.50 \% \\ 53.47 & 54.00 \\ 7.36 & 5 \\ 1,475 & 581 \\ 78 \% & 83.33 \% \\ 49.32 \% & 46.23 \%\end{array}$

Panel C. Test of Differences

\begin{tabular}{|c|c|}
\hline $\begin{array}{c}t \text {-Test } \\
(2)-(6)\end{array}$ & $\begin{array}{l}\text { Wilcoxon } \\
\text { Test } \\
(3)-(7)\end{array}$ \\
\hline $1,430^{* * *}$ & $128^{* \star \star}$ \\
\hline $1,838^{\star \star \star}$ & $358^{* * *}$ \\
\hline 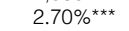 & $1.16 \%^{* \star *}$ \\
\hline $2.05 \%$ *** & $1.09 \%$ *** \\
\hline $4.04 \%^{\star \star \star}$ & $2.06 \%^{* \star \star}$ \\
\hline$-2.69 \%^{\star \star \star}$ & $2.28 \%^{* \star \star}$ \\
\hline$-2.90 \%^{\star \star \star}$ & $2.22 \%^{* *}$ \\
\hline$-9.28 \%^{* \star \star}$ & $4.23 \%$ *** \\
\hline$-0.72 \%^{\star \star \star}$ & $0.07 \%$ \\
\hline$-22.94 \%^{\star \star \star}$ & $-26.80 \%^{* * *}$ \\
\hline$-3.62 \%^{\star \star \star}$ & $-1.39 \%^{* \star *}$ \\
\hline $17^{\star \star \star}$ & $18^{\star \star \star}$ \\
\hline $4,329^{\star \star \star}$ & $516^{\star \star \star}$ \\
\hline $167^{\star \star \star}$ & $106^{\star \star \star}$ \\
\hline $184^{\star \star \star}$ & $132^{\star \star \star}$ \\
\hline $0.02^{\star \star \star}$ & $0.00^{\star \star \star}$ \\
\hline 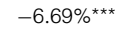 & $-1.00 \%{ }^{\star \star \star}$ \\
\hline $2.11^{\star \star \star}$ & $1.00^{\star \star \star}$ \\
\hline $1.68^{\star \star \star}$ & $2^{\star \star \star}$ \\
\hline $1,598^{\star \star \star}$ & $807^{\star \star \star}$ \\
\hline $2.53 \%^{\star \star \star}$ & $0.01 \%$ \\
\hline$-31.23 \%^{\star \star \star *}$ & $-31.93 \%^{* * *}$ \\
\hline
\end{tabular}


our multivariate analyses, we control for CEO tenure, ownership, and pay, and we examine subsamples of nonfounder CEOs and CEOs with noncontrolling stakes to deal with potential CEO entrenchment in the private-firm sample.

In terms of board independence, we find that public firms have slightly more independent directors on their boards than private firms, probably due to the Sarbanes-Oxley Act of 2002, which requires that the majority of a public firm's board of directors must be independent. Ownership structure is less concentrated in public firms, where the top 5 outside large shareholders own, on average, $18.09 \%$ (median at $14.30 \%$ ), as opposed to $49.32 \%$ (median at $46.23 \%$ ) in private firms. As a result, shareholders in private firms are more empowered to fire an underperforming CEO. Overall, despite some statistically significant differences in firm and CEO characteristics, the private firms in our sample are fairly comparable to the public firms. Nonetheless, we construct a propensity-score-matched sample to check our results from the full sample.

\section{CEO Turnover in Public and Private Firms}

The univariate analysis in the previous section shows that the unconditional turnover rate is higher for CEOs of public firms relative to CEOs of private firms. In this section, we explore the differences in CEO turnover rate and TPS in a multivariate setting.

\section{A. Baseline Results}

To examine how CEO turnover responds to firm performance, we estimate the following baseline regression following prior work (Huson, Parrino, and Starks (2001), Jenter and Kanaan (2015)):

$$
\begin{aligned}
& \operatorname{Pr}(\text { CEO_TURNOVER })=\alpha+\beta_{1} \text { ROA }+\beta_{2} \text { SALES_GROWTH } \\
& +\beta_{3} \text { OTHER_FIRM_CONTROLS }+\beta_{4} \ln (\mathrm{CEO} \text { _TENURE }) \\
& + \text { INDUSTRY_FE }+ \text { YEAR_FE }+\varepsilon,
\end{aligned}
$$

where the dependent variable is CEO_TURNOVER, which takes a value of 1 if a firm changes its CEO in that year, and 0 otherwise. In addition to firm and CEO characteristics, we also include industry fixed effects to control for unobserved industry-specific heterogeneity and year fixed effects to account for the time trend. Table 3 presents the results.

Columns 1 and 3 of Panel A in Table 3 present the regression results from equation (1) where we estimate TPS separately for public and private firms. All of the tables report marginal effects. Marginal effects for continuous variables are computed when all of the independent variables are at their median values; marginal effects for indicator variables are computed when the indicator variables change from 0 to 1 . We show that both public- and private-firm CEO turnover

industry and year with the closest cash flow volatility; ii) the risk-free rate is the 7-year Treasury bond yield prevailing on the grant date; iii) the grant-date stock price is the exercise price (the option is granted at-the-money); iv) the dividend yield is the ratio of the dividend paid out in the last year to the exercise price; and v) the time to maturity is $70 \%$ of the stated maturity. 


\section{TABLE 3}

\section{Difference in CEO TPS Sensitivity between Public and Private Firms}

Table 3 presents the baseline regression model examining the difference in CEO turnover between public and private firms. We report the marginal effects of a logit regression where the dependent variable is CEO_TURNOVER. The marginal effects for continuous variables are computed when all of the independent variables are at their median values. The marginal effects for indicator variables are computed when the indicator variables change from 0 to 1 . Our sample consists of 39,601 public firm-year observations involving 3,815 CEO turnover cases and 6,164 private firm-year observations involving 490 CEO turnover cases from 2001-2011, obtained from Capital IQ. Panel A reports the results using the full sample of public and private firms. Panels B and C report the results by forced and voluntary turnover, respectively. For public firms, we have 1,186 forced turnover cases and 2,629 voluntary turnover cases. For private firms, we have 195 forced turnover cases and 295 voluntary turnover cases. The baseline case is doing nothing. Panel $D$ reports the results using private firms and their propensity-score-matched public firms. We match each private firm to a public firm using the nearest-neighbor algorithm. The variables used for matching include ROA, SALES GROWTH, In(SALES), CF VOLATILITY, LEVERAGE, ACCRUAL, In(FIRM_AGE), In(NUMBER_OF_EMPLOYEES), In(NUMBER_OF_FIRMS_IN_THE_INDUSTRY), In(NUMBER_ OF_FIRMS_IN_THE_STATE), In(CEO_TENURE), CEO_OWNERSHIP, CEO_AGE, INDUSTRY_FE, and YEAR_FE. In column 6 of Panels $A$ and $C$ and column 3 of Panels $B$ and $D$, we include interaction terms between the two performance measures and all firm characteristics (denoted as "Other interactions" but not reported for brevity). Definitions of all variables are provided in the Appendix. All dollar values are in 2011 dollars. All continuous variables are winsorized at the 1st and 99th percentiles. ROA and sales growth are the 2-year cumulative ROA and sales growth from year $t-1$ to year $t$. Industry and year fixed effects are included in the regressions, and the heteroskedasticity-consistent standard errors (reported in square brackets) account for possible correlation within a firm cluster. ${ }^{\star *}$ and ${ }^{\star * *}$ indicate significance at the $5 \%$ and $1 \%$ levels, respectively.

Panel A. Baseline Model of CEO Turnover

\begin{tabular}{|c|c|c|c|c|c|c|}
\hline \multirow[b]{2}{*}{ Variables } & \multicolumn{2}{|c|}{ Public Firms } & \multirow{2}{*}{$\frac{\text { Private Firms }}{3}$} & \multicolumn{3}{|c|}{ Full Sample } \\
\hline & 1 & 2 & & 4 & 5 & 6 \\
\hline PUBLIC & & & & $\begin{array}{l}0.031^{\star \star \star} \\
{[0.010]}\end{array}$ & $\begin{array}{l}0.039^{\star \star \star} \\
{[0.010]}\end{array}$ & $\begin{array}{l}0.041^{* * *} \\
{[0.010]}\end{array}$ \\
\hline PUBLIC $\times$ ROA & & & & & $\begin{array}{l}-0.071^{\star \star \star} \\
{[0.021]}\end{array}$ & $\begin{array}{l}-0.094^{* * *} \\
{[0.033]}\end{array}$ \\
\hline $\begin{array}{l}\text { PUBLIC } \times \\
\text { SALES_GROWTH }\end{array}$ & & & & & $\begin{array}{c}-0.024^{* *} \\
{[0.010]}\end{array}$ & $\begin{array}{c}-0.027^{* *} \\
{[0.012]}\end{array}$ \\
\hline $\mathrm{ROA}$ & $\begin{array}{l}-0.143^{\star \star \star} \\
{[0.051]}\end{array}$ & $\begin{array}{l}-0.136^{\star * *} \\
{[0.049]}\end{array}$ & $\begin{array}{c}-0.096^{\star \star \star} \\
{[0.030]}\end{array}$ & $\begin{array}{l}-0.159^{\star \star \star} \\
{[0.024]}\end{array}$ & $\begin{array}{c}-0.100^{\star \star \star} \\
{[0.023]}\end{array}$ & $\begin{array}{c}-0.118 \\
{[0.088]}\end{array}$ \\
\hline SALES_GROWTH & $\begin{array}{l}-0.045^{\star \star \star} \\
{[0.016]}\end{array}$ & $\begin{array}{l}-0.042^{\star \star \star} \\
{[0.015]}\end{array}$ & $\begin{array}{c}-0.030^{\star \star \star} \\
{[0.011]}\end{array}$ & $\begin{array}{l}-0.050^{\star \star \star} \\
{[0.008]}\end{array}$ & $\begin{array}{l}-0.030^{\star \star \star} \\
{[0.009]}\end{array}$ & $\begin{array}{c}-0.062 \\
{[0.035]}\end{array}$ \\
\hline STOCK_RETURN & & $\begin{array}{l}-0.018^{\star * \star} \\
{[0.007]}\end{array}$ & & & & \\
\hline $\ln (\mathrm{SALES})$ & $\begin{array}{l}0.010^{\star \star \star} \\
{[0.004]}\end{array}$ & $\begin{array}{l}0.010^{\star \star *} \\
{[0.004]}\end{array}$ & $\begin{array}{c}0.010 \\
{[0.005]}\end{array}$ & $\begin{array}{l}0.010^{\star \star \star} \\
{[0.002]}\end{array}$ & $\begin{array}{l}0.010^{\star * \star} \\
{[0.002]}\end{array}$ & $\begin{array}{l}0.009^{* * *} \\
{[0.002]}\end{array}$ \\
\hline CF_VOLATILITY & $\begin{array}{c}0.077 \\
{[0.068]}\end{array}$ & $\begin{array}{c}0.073 \\
{[0.068]}\end{array}$ & $\begin{array}{l}0.565^{\star \star \star} \\
{[0.180]}\end{array}$ & $\begin{array}{l}0.183^{\star \star \star} \\
{[0.068]}\end{array}$ & $\begin{array}{l}0.191^{\star * \star} \\
{[0.069]}\end{array}$ & $\begin{array}{c}0.138 \\
{[0.074]}\end{array}$ \\
\hline LEVERAGE & $\begin{array}{c}-0.005 \\
{[0.008]}\end{array}$ & $\begin{array}{c}-0.006 \\
{[0.008]}\end{array}$ & $\begin{array}{l}0.059^{* *} \\
{[0.026]}\end{array}$ & $\begin{array}{c}0.011 \\
{[0.008]}\end{array}$ & $\begin{array}{c}0.011 \\
{[0.008]}\end{array}$ & $\begin{array}{c}0.012 \\
{[0.009]}\end{array}$ \\
\hline ACCRUAL & $\begin{array}{l}-0.021 \\
{[0.025]}\end{array}$ & $\begin{array}{l}-0.022 \\
{[0.025]}\end{array}$ & $\begin{array}{c}0.081 \\
{[0.054]}\end{array}$ & $\begin{array}{c}-0.009 \\
{[0.023]}\end{array}$ & $\begin{array}{c}0.001 \\
{[0.024]}\end{array}$ & $\begin{array}{c}-0.004 \\
{[0.029]}\end{array}$ \\
\hline In(FIRM_AGE) & $\begin{array}{l}-0.003 \\
{[0.002]}\end{array}$ & $\begin{array}{l}-0.003 \\
{[0.002]}\end{array}$ & $\begin{array}{l}-0.009 \\
{[0.005]}\end{array}$ & $\begin{array}{l}-0.004^{\star \star} \\
{[0.002]}\end{array}$ & $\begin{array}{c}-0.005^{\star \star} \\
{[0.002]}\end{array}$ & $\begin{array}{c}-0.005^{\star *} \\
{[0.002]}\end{array}$ \\
\hline $\begin{array}{l}\text { In(NUMBER_OF_- } \\
\text { EMPLOYEES) }\end{array}$ & $\begin{array}{c}0.000 \\
{[0.002]}\end{array}$ & $\begin{array}{c}0.000 \\
{[0.002]}\end{array}$ & $\begin{array}{c}0.009 \\
{[0.005]}\end{array}$ & $\begin{array}{c}0.002 \\
{[0.002]}\end{array}$ & $\begin{array}{c}0.002 \\
{[0.002]}\end{array}$ & $\begin{array}{l}0.005^{* *} \\
{[0.002]}\end{array}$ \\
\hline $\begin{array}{l}\text { In(NUMBER_OF_FIRMS_ } \\
\text { IN_THE_INDUSTRY) }\end{array}$ & $\begin{array}{l}-0.011 \\
{[0.022]}\end{array}$ & $\begin{array}{l}-0.011 \\
{[0.022]}\end{array}$ & $\begin{array}{c}0.035 \\
{[0.024]}\end{array}$ & $\begin{array}{l}-0.010 \\
{[0.006]}\end{array}$ & $\begin{array}{l}-0.013 \\
{[0.007]}\end{array}$ & $\begin{array}{l}-0.013^{\star *} \\
{[0.007]}\end{array}$ \\
\hline $\begin{array}{l}\text { In(NUMBER_OF_FIRMS_ } \\
\text { IN_THE_STATE) }\end{array}$ & $\begin{array}{c}0.000 \\
{[0.001]}\end{array}$ & $\begin{array}{c}0.000 \\
{[0.001]}\end{array}$ & $\begin{array}{c}0.008 \\
{[0.007]}\end{array}$ & $\begin{array}{c}0.001 \\
{[0.002]}\end{array}$ & $\begin{array}{c}0.001 \\
{[0.002]}\end{array}$ & $\begin{array}{c}0.001 \\
{[0.002]}\end{array}$ \\
\hline In(CEO_TENURE) & $\begin{array}{c}-0.005 \\
{[0.003]}\end{array}$ & $\begin{array}{c}-0.005 \\
{[0.003]}\end{array}$ & $\begin{array}{c}0.002 \\
{[0.008]}\end{array}$ & $\begin{array}{c}-0.005^{\star \star} \\
{[0.002]}\end{array}$ & $\begin{array}{c}-0.006^{\star \star} \\
{[0.002]}\end{array}$ & $\begin{array}{c}-0.006^{* *} \\
{[0.003]}\end{array}$ \\
\hline $\begin{array}{l}\text { INDUSTRY_FE and YEAR_FE } \\
\text { Other interactions }\end{array}$ & $\begin{array}{l}\text { Yes } \\
\text { No }\end{array}$ & $\begin{array}{l}\text { Yes } \\
\text { No }\end{array}$ & $\begin{array}{l}\text { Yes } \\
\text { No }\end{array}$ & $\begin{array}{l}\text { Yes } \\
\text { No }\end{array}$ & $\begin{array}{l}\text { Yes } \\
\text { No }\end{array}$ & $\begin{array}{l}\text { Yes } \\
\text { Yes }\end{array}$ \\
\hline $\begin{array}{l}\text { No. of obs. } \\
\text { Pseudo- } R^{2}\end{array}$ & $\begin{array}{c}39,601 \\
5.2 \%\end{array}$ & $\begin{array}{c}39,601 \\
5.5 \%\end{array}$ & $\begin{array}{l}6,164 \\
7.8 \%\end{array}$ & $\begin{array}{c}45,765 \\
5.1 \%\end{array}$ & $\begin{array}{c}45,765 \\
5.2 \%\end{array}$ & $\begin{array}{c}45,765 \\
5.3 \%\end{array}$ \\
\hline
\end{tabular}


TABLE 3 (continued)

Difference in CEO TPS Sensitivity between Public and Private Firms

\begin{tabular}{|c|c|c|c|c|c|c|}
\hline \multirow[b]{2}{*}{ Variables } & \multicolumn{3}{|c|}{ Panel B. Forced Turnover } & \multicolumn{3}{|c|}{ Panel C. Voluntary Turnover } \\
\hline & 1 & 2 & 3 & 4 & 5 & 6 \\
\hline PUBLIC & $\begin{array}{c}0.018 \\
{[0.023]}\end{array}$ & $\begin{array}{c}0.019 \\
{[0.020]}\end{array}$ & $\begin{array}{c}0.023 \\
{[0.023]}\end{array}$ & $\begin{array}{l}0.031^{\text {*** }} \\
{[0.006]}\end{array}$ & $\begin{array}{l}0.035^{\star \star \star} \\
{[0.007]}\end{array}$ & 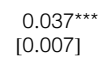 \\
\hline PUBLIC $\times$ ROA & & $\begin{array}{c}-0.047^{* *} \\
{[0.019]}\end{array}$ & $\begin{array}{c}-0.065^{\star *} \\
{[0.033]}\end{array}$ & & $\begin{array}{c}-0.042^{* *} \\
{[0.017]}\end{array}$ & $\begin{array}{c}-0.053^{* *} \\
{[0.027]}\end{array}$ \\
\hline PUBLIC $\times$ SALES_GROWTH & & $\begin{array}{c}-0.039^{* *} \\
{[0.016]}\end{array}$ & $\begin{array}{c}-0.056^{\star *} \\
{[0.024]}\end{array}$ & & $\begin{array}{c}-0.014^{* *} \\
{[0.006]}\end{array}$ & $\begin{array}{l}-0.016^{\star *} \\
{[0.007]}\end{array}$ \\
\hline $\mathrm{ROA}$ & $\begin{array}{l}-0.121^{\star \star \star} \\
{[0.033]}\end{array}$ & $\begin{array}{l}-0.083^{\star \star \star} \\
{[0.027]}\end{array}$ & $\begin{array}{c}0.016 \\
{[0.086]}\end{array}$ & $\begin{array}{c}-0.076^{\star \star \star} \\
{[0.015]}\end{array}$ & $\begin{array}{c}-0.041^{\star *} \\
{[0.016]}\end{array}$ & $\begin{array}{c}-0.046 \\
{[0.064]}\end{array}$ \\
\hline SALES_GROWTH & $\begin{array}{c}-0.063^{\star \star \star} \\
{[0.017]}\end{array}$ & $\begin{array}{c}-0.032^{\star *} \\
{[0.013]}\end{array}$ & $\begin{array}{c}-0.098 \\
{[0.059]}\end{array}$ & $\begin{array}{c}-0.015^{* * *} \\
{[0.003]}\end{array}$ & $\begin{array}{c}-0.004 \\
{[0.005]}\end{array}$ & $\begin{array}{c}-0.013 \\
{[0.021]}\end{array}$ \\
\hline $\ln ($ SALES) & $\begin{array}{l}0.006^{\star \star \star} \\
{[0.002]}\end{array}$ & $\begin{array}{l}0.006^{\star \star \star} \\
{[0.002]}\end{array}$ & $\begin{array}{l}0.005^{\star *} \\
{[0.002]}\end{array}$ & $\begin{array}{l}0.007^{\star * \star} \\
{[0.002]}\end{array}$ & $\begin{array}{l}0.007^{* * *} \\
{[0.002]}\end{array}$ & $\begin{array}{l}0.006^{* * *} \\
{[0.002]}\end{array}$ \\
\hline CF_VOLATILITY & $\begin{array}{c}0.002 \\
{[0.054]}\end{array}$ & $\begin{array}{c}0.009 \\
{[0.056]}\end{array}$ & $\begin{array}{c}0.034 \\
{[0.070]}\end{array}$ & $\begin{array}{l}0.137^{* * *} \\
{[0.052]}\end{array}$ & $\begin{array}{l}0.140^{\text {*** }} \\
{[0.053]}\end{array}$ & $\begin{array}{c}0.099 \\
{[0.055]}\end{array}$ \\
\hline LEVERAGE & $\begin{array}{c}0.002 \\
{[0.008]}\end{array}$ & $\begin{array}{c}0.002 \\
{[0.008]}\end{array}$ & $\begin{array}{c}0.002 \\
{[0.008]}\end{array}$ & $\begin{array}{c}0.009 \\
{[0.006]}\end{array}$ & $\begin{array}{c}0.009 \\
{[0.006]}\end{array}$ & $\begin{array}{c}0.008 \\
{[0.006]}\end{array}$ \\
\hline ACCRUAL & $\begin{array}{c}0.006 \\
{[0.019]}\end{array}$ & $\begin{array}{c}0.014 \\
{[0.019]}\end{array}$ & $\begin{array}{c}0.005 \\
{[0.028]}\end{array}$ & $\begin{array}{c}-0.022 \\
{[0.018]}\end{array}$ & $\begin{array}{c}-0.018 \\
{[0.018]}\end{array}$ & $\begin{array}{c}-0.020 \\
{[0.022]}\end{array}$ \\
\hline In(FIRM_AGE) & $\begin{array}{c}-0.005^{\star *} \\
{[0.002]}\end{array}$ & $\begin{array}{c}-0.006^{* *} \\
{[0.002]}\end{array}$ & $\begin{array}{c}-0.006^{\star *} \\
{[0.003]}\end{array}$ & $\begin{array}{c}-0.001 \\
{[0.001]}\end{array}$ & $\begin{array}{c}-0.001 \\
{[0.001]}\end{array}$ & $\begin{array}{c}-0.001 \\
{[0.002]}\end{array}$ \\
\hline $\begin{array}{c}\text { In(NUMBER_OF- } \\
\text { EMPLOYEES) }\end{array}$ & $\begin{array}{c}0.001 \\
{[0.002]}\end{array}$ & $\begin{array}{c}0.001 \\
{[0.002]}\end{array}$ & $\begin{array}{c}0.003 \\
{[0.002]}\end{array}$ & $\begin{array}{c}0.001 \\
{[0.001]}\end{array}$ & $\begin{array}{c}0.001 \\
{[0.001]}\end{array}$ & $\begin{array}{c}0.003 \\
{[0.001]}\end{array}$ \\
\hline $\begin{array}{l}\text { In(NUMBER_OF_FIRMS_IN_ } \\
\text { THE_INDUSTRY) }\end{array}$ & $\begin{array}{c}0.013 \\
{[0.009]}\end{array}$ & $\begin{array}{c}0.011 \\
{[0.009]}\end{array}$ & $\begin{array}{c}0.013 \\
{[0.010]}\end{array}$ & $\begin{array}{l}-0.015^{\star \star \star} \\
{[0.004]}\end{array}$ & $\begin{array}{l}-0.016^{\star \star \star} \\
{[0.005]}\end{array}$ & $\begin{array}{l}-0.017^{\star \star \star} \\
{[0.005]}\end{array}$ \\
\hline $\begin{array}{l}\text { In(NUMBER_OF_FIRMS_IN_ } \\
\text { THE_STATE) }\end{array}$ & $\begin{array}{c}0.002 \\
{[0.002]}\end{array}$ & $\begin{array}{c}0.002 \\
{[0.002]}\end{array}$ & $\begin{array}{c}0.002 \\
{[0.002]}\end{array}$ & $\begin{array}{l}-0.000 \\
{[0.001]}\end{array}$ & $\begin{array}{l}-0.000 \\
{[0.001]}\end{array}$ & $\begin{array}{l}-0.001 \\
{[0.001]}\end{array}$ \\
\hline In(CEO_TENURE) & $\begin{array}{l}-0.020^{\star \star \star} \\
{[0.006]}\end{array}$ & $\begin{array}{l}-0.020^{\star \star \star} \\
{[0.006]}\end{array}$ & $\begin{array}{l}-0.021^{\star \star \star} \\
{[0.006]}\end{array}$ & $\begin{array}{l}0.005^{\star \star \star} \\
{[0.002]}\end{array}$ & $\begin{array}{l}0.005^{\star \star \star} \\
{[0.002]}\end{array}$ & $\begin{array}{l}0.006^{* * *} \\
{[0.002]}\end{array}$ \\
\hline $\begin{array}{l}\text { INDUSTRY_FE and YEAR_FE } \\
\text { Other interactions }\end{array}$ & $\begin{array}{l}\text { Yes } \\
\text { No }\end{array}$ & $\begin{array}{l}\text { Yes } \\
\text { No }\end{array}$ & $\begin{array}{l}\text { Yes } \\
\text { Yes }\end{array}$ & $\begin{array}{l}\text { Yes } \\
\text { No }\end{array}$ & $\begin{array}{l}\text { Yes } \\
\text { No }\end{array}$ & $\begin{array}{l}\text { Yes } \\
\text { Yes }\end{array}$ \\
\hline $\begin{array}{l}\text { No. of obs. } \\
\text { Pseudo- } R^{2}\end{array}$ & $\begin{array}{l}42,841 \\
10.1 \%\end{array}$ & $\begin{array}{l}42,841 \\
10.3 \%\end{array}$ & $\begin{array}{l}42,841 \\
10.6 \%\end{array}$ & $\begin{array}{c}44,384 \\
3.8 \%\end{array}$ & $\begin{array}{c}44,384 \\
3.9 \%\end{array}$ & $\begin{array}{c}44,384 \\
4.0 \%\end{array}$ \\
\hline \multicolumn{7}{|c|}{ Panel D. Using Private Firms and Their Propensity-Score-Matched Public Firms } \\
\hline Variables & & 1 & & 2 & & 3 \\
\hline PUBLIC & & $\begin{array}{l}0.050^{\star \star} \\
{[0.021]}\end{array}$ & & $\begin{array}{l}0.076^{\star \star \star} \\
{[0.024]}\end{array}$ & & $\begin{array}{l}0.079^{\star \star \star} \\
{[0.024]}\end{array}$ \\
\hline PUBLIC $\times$ ROA & & & & $\begin{array}{l}-0.118^{\star \star} \\
{[0.046]}\end{array}$ & & $\begin{array}{l}-0.154^{\star \star} \\
{[0.064]}\end{array}$ \\
\hline PUBLIC $\times$ SALES_GROWTH & & & & $\begin{array}{l}-0.050^{\star \star \star} \\
{[0.017]}\end{array}$ & & $\begin{array}{c}-0.044^{\star \star} \\
{[0.020]}\end{array}$ \\
\hline $\mathrm{ROA}$ & & $\begin{array}{l}-0.185^{\star \star \star} \\
{[0.040]}\end{array}$ & & $\begin{array}{c}-0.146^{\star \star} \\
{[0.035]}\end{array}$ & & $\begin{array}{c}-0.339 \\
{[0.223]}\end{array}$ \\
\hline SALES_GROWTH & & $\begin{array}{l}-0.047^{\star \star \star} \\
{[0.012]}\end{array}$ & & $\begin{array}{l}-0.028^{\star \star \star} \\
{[0.010]}\end{array}$ & & $\begin{array}{c}-0.053 \\
{[0.077]}\end{array}$ \\
\hline In(SALES) & & $\begin{array}{l}0.017^{\star \star \star} \\
{[0.005]}\end{array}$ & & $\begin{array}{l}0.019^{\star \star \star} \\
{[0.005]}\end{array}$ & & $\begin{array}{l}0.016^{\star \star \star} \\
{[0.005]}\end{array}$ \\
\hline CF_VOLATILITY & & $\begin{array}{l}0.441^{\star \star \star} \\
{[0.156]}\end{array}$ & & $\begin{array}{l}0.489^{\star \star \star} \\
{[0.169]}\end{array}$ & & $\begin{array}{c}0.215 \\
{[0.184]}\end{array}$ \\
\hline LEVERAGE & & $\begin{array}{l}0.061^{\star \star \star} \\
{[0.021]}\end{array}$ & & $\begin{array}{l}0.068^{\text {*** }} \\
{[0.023]}\end{array}$ & & $\begin{array}{l}0.065^{\star \star \star} \\
{[0.023]}\end{array}$ \\
\hline ACCRUAL & & $\begin{array}{c}0.044 \\
{[0.049]}\end{array}$ & & $\begin{array}{c}0.069 \\
{[0.054]}\end{array}$ & & $\begin{array}{c}0.048 \\
{[0.062]}\end{array}$ \\
\hline In(FIRM_AGE) & & $\begin{array}{c}-0.007 \\
{[0.004]}\end{array}$ & & $\begin{array}{c}-0.008 \\
{[0.005]}\end{array}$ & & $\begin{array}{c}-0.011^{\star *} \\
{[0.005]}\end{array}$ \\
\hline
\end{tabular}


TABLE 3 (continued)

Difference in CEO TPS Sensitivity between Public and Private Firms

\begin{tabular}{|c|c|c|c|}
\hline Variables & 1 & 2 & 3 \\
\hline In(NUMBER_OF_EMPLOYEES) & $\begin{array}{c}0.005 \\
{[0.003]}\end{array}$ & $\begin{array}{c}0.005 \\
{[0.004]}\end{array}$ & $\begin{array}{c}0.009^{* *} \\
{[0.004]}\end{array}$ \\
\hline In(NUMBER_OF_FIRMS_IN_THE_INDUSTRY) & $\begin{array}{c}-0.016 \\
{[0.014]}\end{array}$ & $\begin{array}{c}-0.027 \\
{[0.016]}\end{array}$ & $\begin{array}{c}-0.029 \\
{[0.016]}\end{array}$ \\
\hline In(NUMBER_OF_FIRMS_IN_THE_STATE) & $\begin{array}{c}0.004 \\
{[0.005]}\end{array}$ & $\begin{array}{c}0.003 \\
{[0.005]}\end{array}$ & $\begin{array}{c}0.002 \\
{[0.005]}\end{array}$ \\
\hline In(CEO_TENURE) & $\begin{array}{c}-0.001 \\
{[0.001]}\end{array}$ & $\begin{array}{l}-0.001 \\
{[0.001]}\end{array}$ & $\begin{array}{l}-0.001 \\
{[0.001]}\end{array}$ \\
\hline $\begin{array}{l}\text { INDUSTRY_FE and YEAR_FE } \\
\text { Other interactions }\end{array}$ & $\begin{array}{l}\text { Yes } \\
\text { No }\end{array}$ & $\begin{array}{l}\text { Yes } \\
\text { No }\end{array}$ & $\begin{array}{l}\text { Yes } \\
\text { Yes }\end{array}$ \\
\hline $\begin{array}{l}\text { No. of obs. } \\
\text { Pseudo- } R^{2}\end{array}$ & $\begin{array}{c}12,328 \\
6.4 \%\end{array}$ & $\begin{array}{c}12,328 \\
6.7 \%\end{array}$ & $\begin{array}{c}12,328 \\
7.3 \%\end{array}$ \\
\hline
\end{tabular}

respond significantly to bad performance as captured by negative ROA and sales growth, confirming prior evidence that poor performance drives CEO turnover decisions by the board.

One concern is that because public firms can use stock price information, they will naturally rely less on accounting performance measures, leading TPS (based on those measures) to appear lower. Notably, when we add stock return to the public-firm sample in column 2 of Panel A in Table 3, the marginal effects from ROA and sales growth are very close to those in column 1 (and CEO turnover responds significantly to negative stock returns). This suggests that the absence of stock return from the full-sample regression (in column 4) does not bias the underlying coefficient estimates on ROA and sales growth. A Chow (1960) test confirms that the coefficients on ROA and sales growth in the private-firm sample are significantly different from those in the public-firm sample where stock return is included. In the public-firm sample, large firms are associated with high CEO turnover. In the private-firm sample, high cash flow volatility and high leverage are associated with high CEO turnover, suggesting that reliance on internal funding and debt-based external funding leads private-firm shareholders and boards to value cash flow stability.

To test for differential turnover rates and TPS across public and private firms, we estimate the following model of CEO turnover using the full sample of public and private firms:

$$
\begin{aligned}
& \operatorname{Pr}(\text { CEO_TURNOVER })=\alpha+\beta_{1} \text { PUBLIC }+\beta_{2} \text { PUBLIC } \times \text { ROA } \\
& \quad+\beta_{3} \text { PUBLIC } \times \text { SALES_GROWTH }+\beta_{4} \text { ROA } \\
& \quad+\beta_{5} \text { SALES_GROWTH }+\beta_{6} \text { OTHER_FIRM_CONTROLS } \\
& +\beta_{7} \ln (\text { CEO_TENURE })+\text { INDUSTRY_FE }+ \text { YEAR_FE }+\varepsilon,
\end{aligned}
$$

where the key variables of interest are PUBLIC, an indicator variable that takes a value of 1 if a firm is a public firm in that year, and 0 otherwise, and the interaction terms between the public-firm indicator variable and measures of firm 
performance, capturing the incremental differences in CEO TPS in public firms relative to that in private firms. ${ }^{7}$

Column 4 of Panel A in Table 3 presents the regression results from equation (2) without the interaction terms between the public-firm indicator variable and the two performance measures. We find that the baseline turnover rate for publicfirm CEOs is approximately 3 percentage points higher than it is for private-firm CEOs. Compared with unconditional turnover rates of $8 \%-9 \%$, a 3-percentagepoint difference is very significant economically.

Column 5 of Panel A in Table 3 presents the marginal effects from estimating equation (2). Notably, the interaction terms between the public-firm indicator variable and measures of firm performance are all negative and significant at the $5 \%$ level or better. Thus, there is significantly greater CEO TPS in public firms. In terms of the economic significance, when ROA decreases from the sample median to the 25th percentile (a decrease of $9 \%$ ), the probability of CEO turnover in private firms increases by $0.9 \%(=0.100 \times 9 \%)$, whereas the probability of CEO turnover in public firms increases by $1.54 \%(=(0.100+0.071) \times 9 \%)$. Similarly, when sales growth decreases from the sample median to the 25 th percentile (a decrease of 17\%), the probability of CEO turnover in private firms increases by $0.41 \%(=0.024 \times 17 \%)$, in contrast to a much bigger increase in CEO turnover probability of $0.92 \%(=(0.030+0.024) \times 17 \%)$ in public firms. ${ }^{8}$ Column 6 expands equation (2) by adding interaction terms between the two performance measures and all firm characteristics. The interaction terms between the publicfirm indicator variable and measures of firm performance are still negative and significant at the $5 \%$ level or better, and their economic magnitude is similar to that in column 5.

Following Guo and Masulis (2012), we use (high) cash flow volatility and (large) accruals as markers for accounting performance being a noisy signal of the underlying true long-term firm performance. As reported in column 1 of Table IA1 in the Internet Appendix (available at www.jfqa.org), we find that noisy accounting numbers are associated with weaker TPS.

We also attempt to control for potential differences in the CEO candidate pool that could explain the differential TPS in public and private firms (see column 1 of Table IA1). Given that public firms, on average, are larger, older, and have more employees than private firms, they may have a greater internal pool for CEO candidates and thus assess the cost of changing CEOs to be lower. To examine this possibility, we use firm size, firm age, and the number of employees as three proxies for the depth of a firm's internal candidate pool, similar to Borokhovich, Parrino, and Trapani (1996). We find that there are more CEO turnover cases in

\footnotetext{
${ }^{7} \mathrm{Ai}$ and Norton (2003) argue that some adjustment is needed for a correct interpretation of the marginal effect on the interaction terms and propose their way of making the adjustment. However, recent work by Kolasinski and Siegel (2010) shows that this adjustment is inappropriate and that it is perfectly correct to use just the interaction term without any adjustments. Therefore, we do not employ Ai and Norton's (2003) approach in this paper. Nevertheless, in untabulated analyses, we find that our inferences are unchanged based on Ai and Norton's (2003) correction.

${ }^{8}$ In untabulated analyses, we reestimate equation (2) with the use of both contemporaneous and lagged performance measures, and we find similar results. For parsimony, we opted to present our main results using 2-year performance measures.
} 
larger firms and in firms with more employees, consistent with these firms having a deeper internal labor market pool (with the exception of firm age). Further, we use the number of public (private) firms in a given industry and state as measures of the depth of the external candidate pool (although the marginal effects of these variables are mixed). Nonetheless, after adding these proxies for the quality of accounting information and the CEO candidate pool, we continue to find that public-firm CEOs have higher turnover rates and greater TPS. ${ }^{9}$

\section{Forced versus Voluntary Turnover}

The existing literature on CEO turnover has debated whether and how to classify turnover cases into forced versus voluntary ones. On the one hand, voluntary turnover cases may arise due to normal CEO retirement, which need not be associated with poor prior performance (Huson, Malatesta, and Parrino (2004)). On the other hand, Kaplan and Minton (2012) and Jenter and Lewellen (2014) argue that existing algorithms fail to successfully distinguish forced and voluntary turnover, leading to a downward bias in the estimated TPS.

Although our paper is not intended to contribute to this debate, we are interested in whether this classification influences our results on the difference in CEO TPS across public and private firms. Following Parrino (1997), we classify a CEO turnover as forced if the press reports that the CEO is fired or forced out or if the CEO retires or resigns due to pressure. All other departures for CEOs over 60 years old are classified as voluntary. Departures for CEOs younger than 60 years old are also classified as forced if either the press does not report the reason as death, poor health, or the acceptance of another position (including the chairmanship of the board) or if the press reports that the CEO is retiring but does not announce the retirement at least 6 months before the turnover. For public firms, we have 1,186 cases of forced turnover and 2,629 cases of voluntary turnover. For private firms, we have 195 cases of forced turnover and 295 cases of voluntary turnover.

Columns 1-3 (4-6) of Panel B in Table 3 present the regression results based on equation (2), where the dependent variable is the forced (voluntary) CEO turnover indicator variable. The baseline case is no turnover. We find that there is no difference in baseline non-performance-related forced turnover between public- and private-firm CEOs (column 1). These departures could be due to clashes over long-term strategies, management styles, or personalities, and so perhaps it is unsurprising that these idiosyncratic causes do not differ across public and private firms. Conversely, we find that the baseline non-performance-related voluntary turnover rate is significantly higher for public-firm CEOs (column 4). The marginal effect of the public-firm indicator variable is 0.031 and significant at the $1 \%$ level, suggesting a 3-percentage-point-greater baseline voluntary turnover rate. One plausible interpretation of these findings is that public-firm media releases tend to be "gentle" about outgoing CEOs, leading to underclassification of forced CEO turnover cases compared with private firms. Importantly, we still

\footnotetext{
${ }^{9}$ In Table IA 1 in the Internet Appendix, we present the results for Panel A of Table 3 after removing CEOs who are close to retirement (with age $\geq 63$ ), CEOs who are founders, and CEOs with ownership $\geq 10 \%$. We continue to show that there are significantly higher CEO turnover rates and greater CEO TPS in public firms compared with private firms.
} 
observe that irrespective of the nature of the turnover, there is significantly greater CEO TPS in public firms, based on both performance measures (columns 3 and 6).

\section{Matched-Sample Analysis}

In the full sample, public firms are more numerous and broadly different from private firms in the dimensions that we compare. To address the large differences and their possible effects on CEO turnover, we form a matching sample of public firms to our sample of private firms based on the propensity-score-matching approach. We employ the one-to-one nearest-neighbor matching algorithm without replacement, using the full set of firm characteristics in Panel A of Table 3 as well as CEO ownership and age. Panel $\mathrm{C}$ of Table 3 reports the regression results using private firms and their propensity-score-matched public firms. Once the sample is limited to closely matched pairs, the differences in turnover rates and TPS become even starker, with the marginal effects almost doubling.

Overall, the empirical evidence in Table 3 indicates that although poor performance predicts CEO turnover in both public and private firms, public-firm CEOs face higher turnover risk and greater TPS than do private-firm CEOs.

\section{B. Differences in CEO and Board Characteristics and Ownership Concentration}

As shown in Table 2, CEO power and the governance structure are different across these two groups of firms in ways that may contribute to the differences in CEO turnover rate and TPS, such as CEO founder status and board structure. In Table 4, we investigate whether the differential turnover rates and TPS are robust to including the following CEO power/governance variables in the specifications: founder CEO, CEO pay, CEO ownership, board independence, and top 5 ownership (see, e.g., Cornelli et al. (2013), Denis et al. (1997), Kaplan and Minton (2012), and Weisbach (1988)). We find that a founder CEO faces lower TPS (with respect to ROA) than other CEOs, consistent with the conjecture that it is naturally difficult to fire a founder CEO. Interestingly, we find that highly paid CEOs have greater TPS (with respect to sales growth). Not surprisingly, we find that there is significantly lower TPS for CEOs with high ownership stakes (with respect to ROA), whereas there is significantly greater TPS for CEOs with more independent boards (with respect to ROA). Finally, we find that the presence of large shareholders is associated with significantly lower TPS (with respect to ROA). Importantly, after recognizing the public-private firm differences in CEO power, board structure, and ownership structure, public-firm CEOs still experience higher turnover rates and exhibit greater TPS. ${ }^{10}$ In the next section, we examine the effects of investor horizon.

\footnotetext{
${ }^{10}$ In Table IA 2 in the Internet Appendix, we repeat the analysis in Table 4 using the continuous measures of those CEO, board, and ownership characteristics (instead of the indicator variables in the main analysis). We continue to show that there are significantly higher turnover rates and greater CEO TPS in public firms compared with private firms.
} 
TABLE 4

\section{Accounting for CEO, Board, and Ownership Characteristics}

Table 4 examines whether differences in CEO power, board structure, and ownership structure explain the difference in CEO turnover between public and private firms. We report the marginal effects of a logit regression where the dependent variable is CEO_TURNOVER. Marginal effects for continuous variables are computed when all of the independent variables are at their median values. Marginal effects for indicator variables are computed when the indicator variables change from 0 to 1. In column 3, we include interaction terms between the two performance measures and all firm characteristics (denoted as "Other interactions" but not reported for brevity). Definitions of all variables are provided in the Appendix. All dollar values are in 2011 dollars. All continuous variables are winsorized at the 1st and 99th percentiles. ROA and sales growth are the 2-year cumulative ROA and sales growth from year $t-1$ to year $t$. Industry and year fixed effects are included in the regressions, and the heteroskedasticity-consistent standard errors (reported in square brackets) account for possible correlation within a firm cluster. ${ }^{\star \star}$ and ${ }^{\star \star \star}$ indicate significance at the $5 \%$ and $1 \%$ levels, respectively.

Variables
PUBLIC
PUBLIC $\times$ ROA
PUBLIC $\times$ SALES_GROWTH
FOUNDER $\times$ ROA
FOUNDER $\times$ SALES_GROWTH
HIGH_CEO_PAY $\times$ ROA
HIGH_CEO_PAY $\times$ SALES_GROWTH
HIGH_CEO_OWNERSHIP $\times$ ROA
HIGH_CEO_OWNERSHIP $\times$ SALES_GROWTH
HIGH_BOARD_INDEPENDENCE $\times$ ROA
HIGH_BOARD_INDEPENDENCE $\times$ SALES_GROWTH
FOUNDER

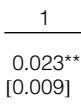

[0.009]

$$
\sqrt{2}+x^{2}
$$

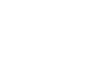

HIGH_CEO_PAY

HIGH_CEO_OWNERSHIP

HIGH_BOARD_INDEPENDENCE

HIGH_TOP5_OWNERSHIP

ROA

SALES_GROWTH

In(SALES)

CF_VOLATILITY

LEVERAGE

ACCRUAL

\begin{tabular}{|c|c|}
\hline 2 & 3 \\
\hline $\begin{array}{l}0.032^{\star \star \star} \\
{[0.009]}\end{array}$ & $\begin{array}{l}0.036^{\star \star \star} \\
{[0.009]}\end{array}$ \\
\hline $\begin{array}{c}-0.060^{\star *} \\
{[0.024]}\end{array}$ & $\begin{array}{c}-0.124^{\star \star \star} \\
{[0.038]}\end{array}$ \\
\hline $\begin{array}{c}-0.029^{\star \star \star} \\
{[0.010]}\end{array}$ & $\begin{array}{c}-0.037^{\star \star \star} \\
{[0.012]}\end{array}$ \\
\hline $\begin{array}{l}0.050^{\star \star} \\
{[0.021]}\end{array}$ & $\begin{array}{c}0.045^{\star *} \\
{[0.022]}\end{array}$ \\
\hline $\begin{array}{c}0.006 \\
{[0.008]}\end{array}$ & $\begin{array}{c}0.010 \\
{[0.009]}\end{array}$ \\
\hline $\begin{array}{l}-0.021 \\
{[0.014]}\end{array}$ & $\begin{array}{c}-0.000 \\
{[0.015]}\end{array}$ \\
\hline $\begin{array}{c}-0.020^{\star *} \\
{[0.009]}\end{array}$ & $\begin{array}{c}-0.032^{\star \star \star} \\
{[0.010]}\end{array}$ \\
\hline $\begin{array}{l}0.048^{\star \star \star} \\
{[0.017]}\end{array}$ & $\begin{array}{l}0.049^{\star \star \star} \\
{[0.017]}\end{array}$ \\
\hline $\begin{array}{c}0.005 \\
{[0.006]}\end{array}$ & $\begin{array}{c}0.008 \\
{[0.007]}\end{array}$ \\
\hline $\begin{array}{c}-0.034^{\star \star} \\
{[0.015]}\end{array}$ & $\begin{array}{c}-0.030^{\star \star} \\
{[0.015]}\end{array}$ \\
\hline $\begin{array}{c}-0.011 \\
{[0.006]}\end{array}$ & $\begin{array}{c}-0.012 \\
{[0.006]}\end{array}$ \\
\hline $\begin{array}{l}0.042^{\star \star \star} \\
{[0.015]}\end{array}$ & $\begin{array}{l}0.047^{\star \star *} \\
{[0.015]}\end{array}$ \\
\hline $\begin{array}{c}0.012^{\star *} \\
{[0.006]}\end{array}$ & $\begin{array}{c}0.011 \\
{[0.006]}\end{array}$ \\
\hline $\begin{array}{c}-0.008 \\
{[0.006]}\end{array}$ & $\begin{array}{c}-0.008 \\
{[0.006]}\end{array}$ \\
\hline $\begin{array}{l}-0.031^{\star \star \star} \\
{[0.007]}\end{array}$ & $\begin{array}{c}-0.029^{\star \star \star} \\
{[0.007]}\end{array}$ \\
\hline $\begin{array}{c}-0.086^{\star \star \star} \\
{[0.017]}\end{array}$ & $\begin{array}{c}-0.087^{\star \star \star} \\
{[0.017]}\end{array}$ \\
\hline $\begin{array}{c}0.003 \\
{[0.004]}\end{array}$ & $\begin{array}{c}0.003 \\
{[0.004]}\end{array}$ \\
\hline $\begin{array}{c}-0.004 \\
{[0.004]}\end{array}$ & $\begin{array}{c}-0.004 \\
{[0.004]}\end{array}$ \\
\hline 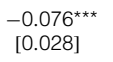 & $\begin{array}{c}0.019 \\
{[0.095]}\end{array}$ \\
\hline $\begin{array}{c}-0.008 \\
{[0.009]}\end{array}$ & $\begin{array}{c}-0.170^{\star \star \star} \\
{[0.051]}\end{array}$ \\
\hline $\begin{array}{l}0.007^{\star \star \star} \\
{[0.002]}\end{array}$ & $\begin{array}{c}0.005^{\star \star} \\
{[0.002]}\end{array}$ \\
\hline $\begin{array}{c}0.135 \\
{[0.075]}\end{array}$ & $\begin{array}{c}0.131 \\
{[0.076]}\end{array}$ \\
\hline $\begin{array}{c}0.009 \\
{[0.008]}\end{array}$ & $\begin{array}{c}0.008 \\
{[0.008]}\end{array}$ \\
\hline $\begin{array}{c}-0.000 \\
{[0.028]}\end{array}$ & $\begin{array}{c}-0.000 \\
{[0.029]}\end{array}$ \\
\hline
\end{tabular}

(continued on next page)

$\begin{array}{ccc}-0.005 & -0.008 & -0.008 \\ {[0.006]} & {[0.006]} & {[0.006]} \\ -0.038^{\star * *} & -0.031^{\star \star *} & -0.029^{\star \star *} \\ {[0.008]} & {[0.007]} & {[0.007]} \\ -0.083^{\star * *} & -0.086^{\star \star *} & -0.087^{\star \star *} \\ {[0.016]} & {[0.017]} & {[0.017]} \\ -0.002 & 0.003 & 0.003 \\ {[0.003]} & {[0.004]} & {[0.004]} \\ 0.002 & -0.004 & -0.004 \\ {[0.004]} & {[0.004]} & {[0.004]} \\ -0.115^{* * *} & -0.076^{\star \star *} & 0.019 \\ {[0.023]} & {[0.028]} & {[0.095]} \\ -0.035^{\star * *} & -0.008 & -0.170^{\star \star *} \\ {[0.007]} & {[0.009]} & {[0.051]} \\ 0.007^{* * *} & 0.007^{\star \star *} & 0.005^{\star *} \\ {[0.002]} & {[0.002]} & {[0.002]} \\ 0.134 & 0.135 & 0.131 \\ {[0.075]} & {[0.075]} & {[0.076]} \\ 0.008 & 0.009 & 0.008 \\ {[0.008]} & {[0.008]} & {[0.008]} \\ -0.007 & -0.000 & -0.000 \\ {[0.028]} & {[0.028]} & {[0.029]}\end{array}$


TABLE 4 (continued)

Accounting for CEO, Board, and Ownership Characteristics

\begin{tabular}{|c|c|c|c|}
\hline Variables & 1 & 2 & 3 \\
\hline In(FIRM_AGE) & $\begin{array}{c}-0.004 \\
{[0.002]}\end{array}$ & $\begin{array}{l}-0.003 \\
{[0.002]}\end{array}$ & $\begin{array}{c}-0.005^{\star \star} \\
{[0.002]}\end{array}$ \\
\hline In(NUMBER_OF_EMPLOYEES) & $\begin{array}{c}0.002 \\
{[0.002]}\end{array}$ & $\begin{array}{c}0.002 \\
{[0.002]}\end{array}$ & $\begin{array}{c}0.004 \\
{[0.002]}\end{array}$ \\
\hline In(NUMBER_OF_FIRMS_IN_THE_INDUSTRY) & $\begin{array}{l}-0.013^{* *} \\
{[0.006]}\end{array}$ & $\begin{array}{c}-0.015^{\star *} \\
{[0.006]}\end{array}$ & $\begin{array}{l}-0.017^{\star \star \star} \\
{[0.006]}\end{array}$ \\
\hline In(NUMBER_OF_FIRMS_IN_THE_STATE) & $\begin{array}{c}0.001 \\
{[0.002]}\end{array}$ & $\begin{array}{c}0.001 \\
{[0.002]}\end{array}$ & $\begin{array}{l}-0.001 \\
{[0.002]}\end{array}$ \\
\hline In(CEO_TENURE) & $\begin{array}{l}0.013^{\star \star \star} \\
{[0.003]}\end{array}$ & $\begin{array}{l}0.012^{\star \star \star} \\
{[0.003]}\end{array}$ & $\begin{array}{c}0.013^{\star \star \star} \\
{[0.004]}\end{array}$ \\
\hline $\begin{array}{l}\text { INDUSTRY_FE and YEAR_FE } \\
\text { Other interactions }\end{array}$ & $\begin{array}{l}\text { Yes } \\
\text { No }\end{array}$ & $\begin{array}{l}\text { Yes } \\
\text { No }\end{array}$ & $\begin{array}{l}\text { Yes } \\
\text { Yes }\end{array}$ \\
\hline $\begin{array}{l}\text { No. of obs. } \\
\text { Pseudo- } R^{2}\end{array}$ & $\begin{array}{c}25,378 \\
7.1 \%\end{array}$ & $\begin{array}{c}25,378 \\
7.9 \%\end{array}$ & $\begin{array}{c}25,378 \\
8.1 \%\end{array}$ \\
\hline
\end{tabular}

\section{Investor Horizon and CEO Turnover}

\section{A. Investor Myopia and CEO Turnover within Public Firms}

To provide evidence on the effect of investor horizon on turnover, we split our public-firm sample into two subsamples: the public firms with more short-term shareholders and the public firms with few short-term shareholders. If investor horizon indeed contributes to the differences between CEO turnover in private and public firms, we would also expect significant differences between these two public-firm subsamples.

Following Brochet, Loumioti, and Serafeim (2015), we first compute a firm's short-term ownership as the difference between ownership by transient institutional investors and ownership by dedicated institutional investors. The definitions of transient and dedicated institutional investors are given in the Appendix and follow Bushee (1998), (2001), who shows that transient investors are more short-term oriented than dedicated investors and that firms with more transient shareholders focus more on short-term earnings than long-term value. We then define SHORT_TERM_PUBLIC as an indicator variable that takes a value of 1 if a firm's short-term ownership is in the top quartile of all public firms, and 0 otherwise. The non-short-term public firm subsample contains firms whose short-term ownership is in the bottom quartile. To alleviate the concern that short-term investors might seek out firms in need of replacing their CEOs, we measure investor horizon 3 years prior to the turnover event so that our measure of the degree to which the firm attracts short- versus long-horizon investors predates the turnover event. In untabulated analyses, we also measure investor horizon at the beginning of the year of the turnover event and find similar results. This is consistent with findings, such as those of Derrien, Kecskés, and Thesmar (2013) and others, that the breakdown of a firm's ownership into short- and long-term investors is fairly stable over time.

We present our results on short-term versus non-short-term public firms in Table 5, which is similar to Table 3 except that we replace the public-firm indicator variable and its interactions with the short-term public-firm indicator variable. 
TABLE 5

Investor Horizon and CEO Turnover within Public Firms

Table 5 examines how the variations in investor myopia within public firms influence the CEO turnover decision. We report the marginal effects of a logit regression where the dependent variable is CEO_TURNOVER. The marginal effects for continuous variables are computed when all of the independent variables are at their median values. The marginal effects for indicator variables are computed when the indicator variables change from 0 to 1 . The sample consists of short-term public firms and non-short-term public firms. Short-term public firms are the public firms whose short-term investor ownership (the difference between ownership by transient institutional investors and ownership by dedicated institutional investors) is in the top quartile of all public firms. Non-short-term public firms are the public firms whose short-term investor ownership is in the bottom quartile of all public firms. The tilt of a firm's ownership toward long versus short-horizon investors is typically fairly stable, so we measure investor horizon 3 years prior to the turnover event to avoid any anticipatory buying by short-term investors. In column 3, we include interaction terms between the two performance measures and all firm characteristics (denoted as "Other interactions" but not reported for brevity). Definitions of all variables are provided in the Appendix. All dollar values are in 2011 dollars. All continuous variables are winsorized at the 1st and 99th percentiles. Industry and year fixed effects are included in the regressions, and the heteroskedasticityconsistent standard errors (reported in square brackets) account for possible correlation within a firm cluster. ${ }^{\star \star}$ and ${ }^{\star \star \star}$ indicate significance at the $5 \%$ and $1 \%$ levels, respectively.

\begin{tabular}{|c|c|c|c|}
\hline Variables & 1 & 2 & 3 \\
\hline SHORT_TERM_PUBLIC & $\begin{array}{l}0.028^{* *} \\
{[0.014]}\end{array}$ & $\begin{array}{l}0.047^{\star \star} \\
{[0.021]}\end{array}$ & $\begin{array}{l}0.049 * \star \\
{[0.022]}\end{array}$ \\
\hline SHORT_TERM_PUBLIC $\times$ ROA & & $\begin{array}{c}-0.145^{\star \star} \\
{[0.067]}\end{array}$ & $\begin{array}{c}-0.148^{\star \star} \\
{[0.069]}\end{array}$ \\
\hline SHORT_TERM_PUBLIC $\times$ SALES_GROWTH & & $\begin{array}{c}-0.062^{\star \star} \\
{[0.030]}\end{array}$ & $\begin{array}{c}-0.070^{\star \star} \\
{[0.033]}\end{array}$ \\
\hline $\mathrm{ROA}$ & $\begin{array}{c}-0.215^{\star \star} \\
{[0.093]}\end{array}$ & $\begin{array}{c}-0.132^{\star \star} \\
{[0.060]}\end{array}$ & $\begin{array}{c}0.321 \\
{[0.280]}\end{array}$ \\
\hline SALES_GROWTH & $\begin{array}{c}-0.068^{\star *} \\
{[0.030]}\end{array}$ & $\begin{array}{c}-0.037^{\star \star} \\
{[0.018]}\end{array}$ & $\begin{array}{c}-0.180 \\
{[0.142]}\end{array}$ \\
\hline In(SALES) & $\begin{array}{c}0.011 \\
{[0.007]}\end{array}$ & $\begin{array}{c}0.011 \\
{[0.007]}\end{array}$ & $\begin{array}{c}0.011 \\
{[0.007]}\end{array}$ \\
\hline CF_VOLATILITY & $\begin{array}{c}0.154 \\
{[0.158]}\end{array}$ & $\begin{array}{c}0.113 \\
{[0.154]}\end{array}$ & $\begin{array}{c}0.100 \\
{[0.162]}\end{array}$ \\
\hline LEVERAGE & $\begin{array}{c}0.006 \\
{[0.018]}\end{array}$ & $\begin{array}{c}0.000 \\
{[0.018]}\end{array}$ & $\begin{array}{c}-0.004 \\
{[0.019]}\end{array}$ \\
\hline ACCRUAL & $\begin{array}{c}-0.065 \\
{[0.064]}\end{array}$ & $\begin{array}{c}-0.052 \\
{[0.062]}\end{array}$ & $\begin{array}{c}0.011 \\
{[0.062]}\end{array}$ \\
\hline In(FIRM_AGE) & $\begin{array}{c}0.004 \\
{[0.005]}\end{array}$ & $\begin{array}{c}0.004 \\
{[0.005]}\end{array}$ & $\begin{array}{c}0.009 \\
{[0.006]}\end{array}$ \\
\hline In(NUMBER_OF_EMPLOYEES) & $\begin{array}{c}0.003 \\
{[0.005]}\end{array}$ & $\begin{array}{c}0.004 \\
{[0.005]}\end{array}$ & $\begin{array}{c}0.003 \\
{[0.005]}\end{array}$ \\
\hline In(NUMBER_OF_FIRMS_IN_THE_INDUSTRY) & $\begin{array}{c}0.045 \\
{[0.073]}\end{array}$ & $\begin{array}{c}0.038 \\
{[0.071]}\end{array}$ & $\begin{array}{c}0.041 \\
{[0.074]}\end{array}$ \\
\hline In(NUMBER_OF_FIRMS_IN_THE_STATE) & $\begin{array}{c}-0.001 \\
{[0.003]}\end{array}$ & $\begin{array}{c}-0.002 \\
{[0.003]}\end{array}$ & $\begin{array}{c}-0.001 \\
{[0.004]}\end{array}$ \\
\hline In(CEO_TENURE) & $\begin{array}{c}-0.007 \\
{[0.005]}\end{array}$ & $\begin{array}{c}-0.006 \\
{[0.005]}\end{array}$ & $\begin{array}{c}-0.008 \\
{[0.006]}\end{array}$ \\
\hline $\begin{array}{l}\text { INDUSTRY_FE and YEAR_FE } \\
\text { Other interactions }\end{array}$ & $\begin{array}{l}\text { Yes } \\
\text { No }\end{array}$ & $\begin{array}{l}\text { Yes } \\
\text { No }\end{array}$ & $\begin{array}{l}\text { Yes } \\
\text { Yes }\end{array}$ \\
\hline $\begin{array}{l}\text { No. of obs. } \\
\text { Pseudo- } R^{2}\end{array}$ & $\begin{array}{c}18,408 \\
5.4 \%\end{array}$ & $\begin{array}{c}18,408 \\
5.9 \%\end{array}$ & $\begin{array}{c}18,408 \\
6.3 \%\end{array}$ \\
\hline
\end{tabular}

In column 1 of Table 5, we show that the marginal effect of the short-term publicfirm indicator variable is 0.028 and significant at the $5 \%$ level, suggesting that there is a greater unconditional turnover rate in the short-term public-firm subsample. Column 3 present the results including the interaction terms between the short-term public-firm indicator variable and the two performance measures and interaction terms between the two performance measures and all firm characteristics. We find that the interactions of the short-term public-firm indicator variable 
and the two performance measures are negative and significant at the 5\% level. ${ }^{11}$ Overall, the results in Table 5 show that within-public-firm variation in investor myopia helps explain the differential CEO turnover rates and TPS between public and private firms. This provides suggestive evidence that the differences in publicversus private-firm investor horizon help explain the CEO turnover differences between public and private firms.

\section{B. Performance Changes after CEO Turnover}

The higher CEO turnover rate and greater TPS in public firms compared with those in private firms can be interpreted as either public firms firing their CEOs too quickly or private firms firing their CEOs too slowly. Indeed, it is also possible that the differential turnover rates are each optimal for their respective groups of firms. Huson et al. (2004) suggest that changes in firm performance following CEO turnover convey the quality of the turnover decision. In this section, we examine performance changes after turnover in order to gain insight into the optimality of the turnover decision. If the greater TPS in public firms is driven by investor myopia, then we will see smaller performance improvements following publicfirm CEO turnover.

We match each CEO turnover event firm to a control firm following Boone and Ivanov (2012). We first identify a group of firms with no CEO turnover in the same Fama and French (1997) 48 industries whose sales in year 0 are within $[50 \%, 150 \%]$ of the sales of the turnover firm. Among them, we then pick the control firm with the closest 2-year cumulative ROA (sales growth) in year -1 and year 0 . If the control firm drops out of the sample in the period from year +1 to year +3 , we then select the firm with the next closest 2-year cumulative ROA (sales growth). We compute the control-adjusted performance of each turnover event firm by subtracting the performance of its control firm. Similar to the matching approach advocated by Barber and Lyon (1996), our method can help isolate the component of performance change attributable to turnover from that due to mean reversion in performance time series.

Panel A of Table 6 presents the results on control-adjusted performance after CEO turnover. The fact that both the control-adjusted ROA and control-adjusted sales growth are close to 0 in the period from year -1 to year 0 indicates that the matching was sufficiently close. These two performance measures are both positive and significant in the period from year +1 to year +3 , indicating that firm performance does improve following CEO turnover. Importantly, the performance turnaround is more pronounced for private firms than for public firms. Taking year +1 , for example, the mean (median) of control-adjusted ROA for private firms at $3.53 \%(1.66 \%)$ is significantly larger than that for public firms at $2.32 \%(0.58 \%)$. Similarly, the mean (median) control-adjusted sales growth for private firms of $16.02 \%(8 \%)$ is significantly larger than it is for public firms at $9.18 \%(3.67 \%)$.

Panel A of Table 6 uses control-adjusted performance, so the interpretation is, for example, that for given performance, a public firm that replaces its CEO

\footnotetext{
${ }^{11}$ In Table IA 3 in the Internet Appendix, we repeat the analysis in Table 5 by further controlling for CEO, board, and ownership characteristics. We continue to show that there are significantly higher turnover rates and greater CEO TPS in the short-term public-firm subsample compared with the nonshort-term public-firm subsample.
} 
sees improvement relative to one that does not. Further, the control-adjusted improvement is smaller than it is following private-firm turnover. Next, we estimate the following regression to explain differences in performance improvement in the year following CEO turnover across public and private firms:

$$
\begin{aligned}
& \text { POST_TURNOVER_PERFORMANCE_CHANGE } \\
& =\alpha+\beta_{1} \text { PUBLIC_TURNOVER }+\beta_{2} \text { PRIVATE_TURNOVER } \\
& +\beta_{3} \text { OTHER_FIRM_CONTROLS }+\beta_{4} \ln \text { (CEO_TENURE) } \\
& +\beta_{5} \text { PRE_TURNOVER_PERFORMANCE } \\
& + \text { INDUSTRY_FE + YEAR_FE }+\varepsilon \text {, }
\end{aligned}
$$

where the dependent variable is post-turnover performance change, measured by $\triangle$ ROA (or $\triangle$ SALES_GROWTH) from the turnover year (i.e., year 0 ) to the post-turnover period (year +1 to year +3 ). Our variables of interest are the two indicator variables PUBLIC_TURNOVER and PRIVATE_TURNOVER, where PUBLIC_TURNOVER (PRIVATE_TURNOVER) takes a value of 1 if a public (private) firm changes its CEO in year 0 , and 0 otherwise. We control for the lagged performance so that we examine the post-turnover performance improvement while holding the pre-turnover performance constant. By doing so, differing post-turnover performance improvement between public and private firms cannot be attributed to differences in the observed pre-turnover performance. Panel B of Table 6 presents the results.

TABLE 6

Firm Performance Changes after CEO Turnover

Table 6 presents firm performance improvement after CEO turnover. Definitions of all variables are provided in the Appendix. All dollar values are in 2011 dollars. All continuous variables are winsorized at the 1 st and 99 th percentiles. Panel A presents the results on control-adjusted performance. In columns 1 and 2 of Panel $B$, the dependent variables are $\triangle R O A$ and $\triangle$ SALES_GROWTH, respectively. In Panels $C$ and D, we repeat the analysis in Panels $A$ and $B$, respectively, by focusing on short-term public firms and non-short-term public firms. Short-term public firms are the public firms whose short-term investor ownership (the difference between ownership by transient institutional investors and ownership by dedicated institutional investors) is in the top quartile of all public firms. Non-short-term public firms are the public firms whose short-term investor ownership is in the bottom quartile of all public firms. We measure investor horizon 3 years prior to the turnover event to avoid any anticipatory buying by short-term investors. Industry and year fixed effects are

\begin{tabular}{|c|c|c|c|c|c|c|}
\hline & Public & Firms & Private & Firms & $\begin{array}{r}\text { Te } \\
\text { Differ }\end{array}$ & $\begin{array}{l}\text { st of } \\
\text { ences }\end{array}$ \\
\hline Variable & $\begin{array}{c}\text { Mean } \\
1 \\
\end{array}$ & $\begin{array}{c}\text { Median } \\
2 \\
\end{array}$ & $\begin{array}{c}\text { Mean } \\
3 \\
\end{array}$ & $\begin{array}{c}\text { Median } \\
4 \\
\end{array}$ & $\begin{array}{c}t \text {-Test } \\
(1)-(3) \\
\end{array}$ & $\begin{array}{l}\text { Wilcoxon } \\
\text { Test } \\
(2)-(4)\end{array}$ \\
\hline $\begin{array}{l}\text { CONTROL_ADJUSTED_ROA in year }-1 \\
\text { CONTROL_ADJUSTED_ROA in year } 0 \\
\text { CONTROL_ADJUSTED_ROA in year }+1 \\
\text { CONTROL_ADJUSTED_ROA in year }+2 \\
\text { CONTROL_ADJUSTED_ROA in year }+3\end{array}$ & $\begin{array}{l}0.43 \% \\
0.69 \% \\
2.32 \% \\
2.03 \% \\
2.31 \%\end{array}$ & $\begin{array}{r}-0.03 \% \\
0.08 \% \\
0.58 \% \\
0.95 \% \\
0.91 \%\end{array}$ & $\begin{array}{r}-0.23 \% \\
0.76 \% \\
3.53 \% \\
3.28 \% \\
3.96 \%\end{array}$ & $\begin{array}{l}0.04 \% \\
0.42 \% \\
1.66 \% \\
2.10 \% \\
2.04 \%\end{array}$ & $\begin{array}{l}0.66 \% \\
-0.1 \% \\
-1.21 \% \text { ** } \\
-1.25 \% \\
-1.65 \%\end{array}$ & $\begin{array}{l}-0.07 \% \\
-0.34 \% \\
-1.08 \%^{* * *} \\
-1.15 \%^{* \star *} \\
-1.13 \%^{* \star *}\end{array}$ \\
\hline $\begin{array}{l}\text { CONTROL_ADJUSTED_SALES_GROWTH in year }-1 \\
\text { CONTROL_ADJUSTED_SALES_GROWTH in year } 0 \\
\text { CONTROL_ADJUSTED_SALES_GROWTH in year }+1 \\
\text { CONTROL_ADJUSTED_SALES_GROWTH in year }+2 \\
\text { CONTROL_ADJUSTED_SALES_GROWTH in year }+3\end{array}$ & $\begin{array}{r}-2.14 \% \\
2.78 \% \\
9.18 \% \\
8.15 \% \\
8.28 \%\end{array}$ & $\begin{array}{r}-1.15 \% \\
0.01 \% \\
3.67 \% \\
3.59 \% \\
3.90 \%\end{array}$ & $\begin{array}{r}-1.60 \% \\
1.38 \% \\
16.02 \% \\
13.28 \% \\
13.31 \%\end{array}$ & $\begin{array}{r}-1.21 \% \\
-0.58 \% \\
8.00 \% \\
6.73 \% \\
7.63 \%\end{array}$ & $\begin{array}{l}-0.54 \% \\
1.40 \% \\
-6.84 \%^{* \star *} \\
-5.13 \%^{* *} \\
-5.03 \%\end{array}$ & $\begin{array}{c}0.06 \% \\
0.59 \% \\
-4.33 \%^{\star \star \star} \\
-3.14 \%^{\star \star \star} \\
-3.73 \%^{\star \star \star}\end{array}$ \\
\hline
\end{tabular}
included in the regressions, and the heteroskedasticity-consistent standard errors (reported in square brackets) account for possible correlation within a firm cluster. ${ }^{* \star}$ and ${ }^{* \star *}$ indicate significance at the $5 \%$ and $1 \%$ levels, respectively. The F-statistics to test the equality of PUBLIC_TURNOVER and PRIVATE_TURNOVER are provided at the bottom of the table. Panel A. Control-Adjusted Performance in Public and Private Firms 
Firm Performance Changes after CEO Turnover

Panel B. Operating Performance Improvement in Public and Private Firms

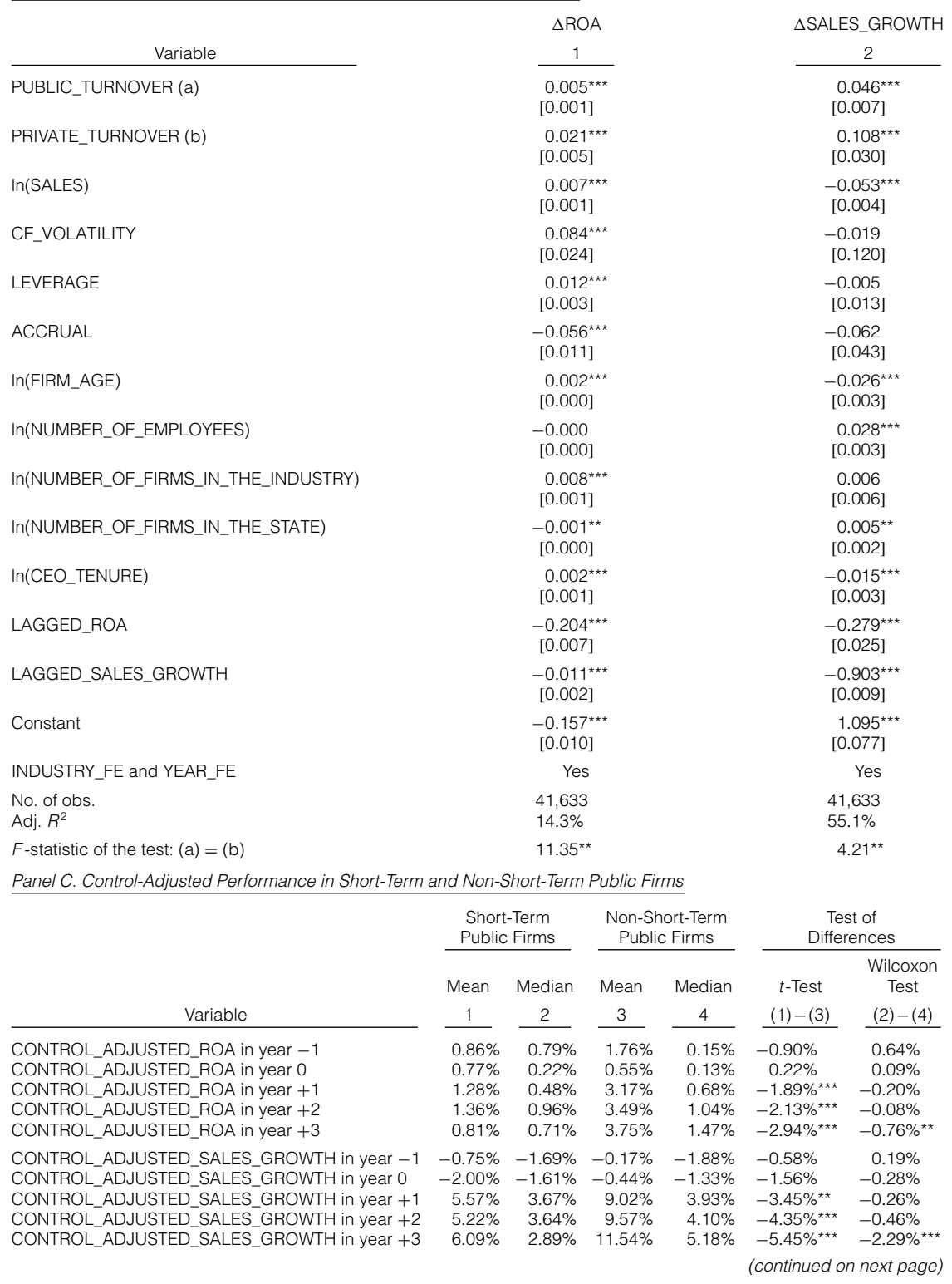


TABLE 6 (continued)

Firm Performance Changes after CEO Turnover

Panel D. Operating Performance Improvement in Short-Term and Non-Short-Term Public Firms

\begin{tabular}{|c|c|c|}
\hline Variable & $\begin{array}{c}\Delta \mathrm{ROA} \\
1\end{array}$ & $\begin{array}{c}\Delta \text { SALES_GROWTH } \\
2\end{array}$ \\
\hline SHORT_TERM_PUBLIC_TURNOVER (a) & $\begin{array}{c}0.002 \\
{[0.003]}\end{array}$ & $\begin{array}{c}0.006 \\
{[0.014]}\end{array}$ \\
\hline NON_SHORT_TERM_PUBLIC_TURNOVER (b) & $\begin{array}{l}0.013^{\star \star \star} \\
{[0.004]}\end{array}$ & $\begin{array}{l}0.089^{\star \star \star} \\
{[0.015]}\end{array}$ \\
\hline In(SALES) & $\begin{array}{l}0.005^{\star \star *} \\
{[0.001]}\end{array}$ & $\begin{array}{l}-0.052^{\star \star \star} \\
{[0.006]}\end{array}$ \\
\hline CF_VOLATILITY & $\begin{array}{c}-0.020 \\
{[0.040]}\end{array}$ & $\begin{array}{c}-0.086 \\
{[0.148]}\end{array}$ \\
\hline LEVERAGE & $\begin{array}{l}0.017^{\star \star \star} \\
{[0.004]}\end{array}$ & $\begin{array}{c}-0.019 \\
{[0.016]}\end{array}$ \\
\hline ACCRUAL & $\begin{array}{l}0.121^{\star \star *} \\
{[0.017]}\end{array}$ & $\begin{array}{c}0.001 \\
{[0.051]}\end{array}$ \\
\hline In(FIRM_AGE) & $\begin{array}{l}0.002^{\star \star \star} \\
{[0.001]}\end{array}$ & $\begin{array}{l}-0.020^{\star \star \star} \\
{[0.004]}\end{array}$ \\
\hline In(NUMBER_OF_EMPLOYEES) & $\begin{array}{l}-0.001 \\
{[0.001]}\end{array}$ & $\begin{array}{l}0.036^{\star \star \star} \\
{[0.006]}\end{array}$ \\
\hline In(NUMBER_OF_FIRMS_IN_THE_INDUSTRY) & $\begin{array}{c}0.001 \\
{[0.001]}\end{array}$ & $\begin{array}{c}0.037 \\
{[0.039]}\end{array}$ \\
\hline In(NUMBER_OF_FIRMS_IN_THE_STATE) & $\begin{array}{l}-0.001^{\star \star} \\
{[0.001]}\end{array}$ & $\begin{array}{c}0.003 \\
{[0.003]}\end{array}$ \\
\hline In(CEO_TENURE) & $\begin{array}{c}0.000 \\
{[0.001]}\end{array}$ & $\begin{array}{l}-0.012^{\star \star \star} \\
{[0.003]}\end{array}$ \\
\hline PRE_TURNOVER_ROA & $\begin{array}{l}-0.246^{\star \star \star} \\
{[0.010]}\end{array}$ & $\begin{array}{l}-0.207^{\star \star \star} \\
{[0.031]}\end{array}$ \\
\hline PRE_TURNOVER_SALES_GROWTH & $\begin{array}{l}-0.010^{\star \star \star} \\
{[0.003]}\end{array}$ & $\begin{array}{l}-0.875^{\star \star \star} \\
{[0.014]}\end{array}$ \\
\hline Constant & $\begin{array}{l}-0.088^{\star \star \star} \\
{[0.014]}\end{array}$ & $\begin{array}{l}0.790 * * * \\
{[0.168]}\end{array}$ \\
\hline INDUSTRY_FE and YEAR_FE & Yes & Yes \\
\hline $\begin{array}{l}\text { No. of obs. } \\
\text { Adj. } R^{2}\end{array}$ & $\begin{array}{l}17,509 \\
20.5 \%\end{array}$ & $\begin{array}{l}17,509 \\
58.9 \%\end{array}$ \\
\hline$F$-statistic of the test: $(a)=(b)$ & $5.85^{\star \star}$ & $17.80^{\star \star \star}$ \\
\hline
\end{tabular}

In column 1 of Panel $\mathrm{B}$ in Table 6 , the dependent variable is $\triangle \mathrm{ROA}$, and the coefficients corresponding to the public and private turnover indicators are 0.005 and 0.021 , respectively, both significant at the $1 \%$ level. An $F$-test rejects equality of these two effects at the $1 \%$ level. This result indicates that although both groups of firms show some performance improvement after CEO turnover, the improvement is more pronounced in private firms. We find similar results when the performance measure is $\triangle$ SALES_GROWTH in column 2.

In Panels $\mathrm{C}$ and $\mathrm{D}$ of Table 6, we examine within-public-firm differences in performance improvement following CEO turnover by focusing on short-term versus non-short-term public firms. Consistent with the pattern between public and private firms, we find that the post-turnover performance improvement is more pronounced in non-short-term public firms.

Overall, Table 6 shows that the performance improvement around CEO turnover is more evident for private firms than for public firms, and within public firms, it is more evident for non-short-term public firms. Although we cannot establish it conclusively, this evidence is consistent with one implication of investor 
myopia, specifically, that CEOs of public firms are often prematurely dismissed. Our results are also consistent with those of Fisman et al. (2014), who caution that insulation from (public) shareholder pressure on short-term results may allow for better long-term corporate decision making and that greater CEO TPS may have unintended consequences.

\section{Instrumental Variable Approach}

Whenever two groups of firms are compared, one should be concerned that some underlying difference between the two groups is the true cause of the results. Here, membership in each group is endogenous because going public or staying private is a choice. Although firms may choose to be public or private for various reasons, there is little reason to believe that managing CEO TPS is the primary motive for a firm's decision to become public or stay private. We therefore believe that our results are unlikely to be subject to any reverse-causality concerns.

It is still possible that some omitted variables drive both a firm's public/ private decision and its CEO turnover decisions. In this section, we apply a 2-stage least squares (2SLS) regression with an instrumental variable (IV). Our IV is the state-level household stock market participation rate. It is widely documented that households tend to hold stocks of local public firms (Coval and Moskowitz (1999)), and thus households participate more in the stock market if there are a large number of local public firms (Brown, Ivkovic, Smith, and Weisbenner (2008)). For this reason, we expect a positive association between local households' stock market participation and the prevalence of local public firms (satisfying the relevance condition).

We construct the state-level household stock market participation rate based on the Panel Study of Income Dynamics (PSID) database, which is a survey of representative U.S. individuals and families compiled by the University of Michigan. The state-level household stock market participation rate is computed as the number of households that make non-zero stock investments divided by the total number of households in a state. We use the survey data from 1984, which is the earliest year with available information on household stock holdings. There is an approximately 20-year gap between 1984 when our IV is measured and our sample period of 2001-2011 when CEO turnover takes place, and thus the stock market participation rate in 1984 is unlikely to directly influence CEO turnover cases almost 20 years later (other than through the channel of being publicly listed, satisfying the exclusion condition). ${ }^{12}$

In the first stage, we run a regression with the public-firm indicator variable as the dependent variable. The independent variables include the state-level household stock market participation rate (the IV) and the firm characteristics used in equation (1). In the second stage, we reestimate equation (2) using the predicted value of the public-firm indicator variable obtained from the first stage. In both stages, we use a linear probability model instead of a logit model because

\footnotetext{
${ }^{12}$ In untabulated analyses, we also use the contemporaneous stock market participation rate as the IV, and our results are similar. Stock market participation rates are fairly stable, perhaps indicating a learned behavior passed through generations or peer interactions.
} 
in the context of 2SLS, only the former yields consistent second-stage estimates (Angrist (2001), Angrist and Krueger (2001)).

Column 1 of Table 7 presents the results of the first-stage regression. The coefficient for state-level household stock market participation rate is positive and significant at the $1 \%$ level, indicating that households' participation in the stock market almost 20 years ago is positively associated with the current prevalence of local public firms. Column 2 presents the second-stage regression results. We still find that public-firm CEOs have higher turnover rates and greater TPS than

\section{TABLE 7}

The Instrumental Variable Approach (2SLS)

Table 7 presents 2-stage least squares (2SLS) regression results. Column 1 reports the first-stage linear probability regression of the likelihood of a firm being publicly listed. The instrumental variable is the state-level household stock market participation rate in 1984. Column 2 reports the estimates from the second-stage linear probability regression where the dependent variable is CEO_TURNOVER and the independent variables are the same as the ones in column 6 of Panel A in Table 3. Definitions of all variables are provided in the Appendix. All dollar values are in 2011 dollars. All continuous variables are winsorized at the 1st and 99th percentiles. ROA and sales growth are the 2-year cumulative $\mathrm{ROA}$ and sales growth from year $t-1$ to year $t$. Industry and year fixed effects are included in the regressions, and the heteroskedasticity-consistent standard errors (reported in square brackets) account for possible correlation within a firm cluster. ${ }^{* *}$ and ${ }^{* \star *}$ indicate significance at the $5 \%$ and $1 \%$ levels, respectively.

\begin{tabular}{|c|c|c|}
\hline \multirow[b]{2}{*}{ Variable } & $\begin{array}{c}\text { First-Stage Predicting } \\
\text { PUBLIC }\end{array}$ & $\begin{array}{c}\text { Second-Stage Explaining } \\
\text { CEO_TURNOVER }\end{array}$ \\
\hline & 1 & 2 \\
\hline PUBLIC & & $\begin{array}{l}0.105^{\star \star} \\
{[0.044]}\end{array}$ \\
\hline PUBLIC $\times$ ROA & & $\begin{array}{l}-0.100^{\star \star \star} \\
{[0.028]}\end{array}$ \\
\hline PUBLIC $\times$ SALES_GROWTH & & $\begin{array}{l}-0.030^{\star \star \star} \\
{[0.009]}\end{array}$ \\
\hline $\mathrm{ROA}$ & $\begin{array}{c}0.001 \\
{[0.003]}\end{array}$ & $\begin{array}{l}-0.164^{\star \star} \\
{[0.077]}\end{array}$ \\
\hline SALES_GROWTH & $\begin{array}{c}0.001 \\
{[0.001]}\end{array}$ & $\begin{array}{c}-0.046^{\star *} \\
{[0.018]}\end{array}$ \\
\hline $\ln (\mathrm{SALES})$ & $\begin{array}{l}0.005^{\star \star \star} \\
{[0.001]}\end{array}$ & $\begin{array}{l}0.004^{\star \star \star} \\
{[0.002]}\end{array}$ \\
\hline CF_VOLATILITY & $\begin{array}{l}0.068^{* \star \star} \\
{[0.025]}\end{array}$ & $\begin{array}{l}0.198^{* \star *} \\
{[0.062]}\end{array}$ \\
\hline LEVERAGE & $\begin{array}{l}-0.086^{\star \star \star} \\
{[0.003]}\end{array}$ & $\begin{array}{c}0.013 \\
{[0.008]}\end{array}$ \\
\hline ACCRUAL & $\begin{array}{c}-0.011 \\
{[0.009]}\end{array}$ & $\begin{array}{c}0.030 \\
{[0.022]}\end{array}$ \\
\hline In(FIRM_AGE) & $\begin{array}{l}0.022^{* \star *} \\
{[0.001]}\end{array}$ & $\begin{array}{c}-0.005^{\star *} \\
{[0.002]}\end{array}$ \\
\hline \multirow[t]{2}{*}{ In(NUMBER_OF_EMPLOYEES) } & $0.005^{\star \star \star}$ & $0.005^{\star \star \star}$ \\
\hline & [0.001] & [0.002] \\
\hline In(NUMBER_OF_FIRMS_IN_THE_INDUSTRY) & $\begin{array}{l}0.436^{\star \star \star} \\
{[0.001]}\end{array}$ & $\begin{array}{c}-0.034 \\
{[0.018]}\end{array}$ \\
\hline In(NUMBER_OF_FIRMS_IN_THE_STATE) & $\begin{array}{l}0.034^{\star \star \star} \\
{[0.001]}\end{array}$ & $\begin{array}{c}-0.002 \\
{[0.002]}\end{array}$ \\
\hline In(CEO_TENURE) & $\begin{array}{l}0.005^{\star \star \star} \\
{[0.001]}\end{array}$ & $\begin{array}{l}-0.008^{\star \star \star} \\
{[0.002]}\end{array}$ \\
\hline STATE_LEVEL_STOCK_MARKET_PARTICIPATION_RATE (IV) & $\begin{array}{l}0.046^{\star \star \star} \\
{[0.008]}\end{array}$ & \\
\hline $\begin{array}{l}\text { INDUSTRY_FE and YEAR_FE } \\
\text { Other interactions }\end{array}$ & $\begin{array}{l}\text { Yes } \\
\text { No }\end{array}$ & $\begin{array}{l}\text { Yes } \\
\text { Yes }\end{array}$ \\
\hline $\begin{array}{l}\text { No. of obs. } \\
\text { Adj. } R^{2}\end{array}$ & $\begin{array}{l}45,765 \\
44.1 \%\end{array}$ & $\begin{array}{c}45,765 \\
3.2 \%\end{array}$ \\
\hline$F$-statistic of the test: IV $=0$ & $12.58^{\star \star \star}$ & \\
\hline
\end{tabular}


private-firm CEOs. ${ }^{13}$ Overall, the documented public-private firm differences in CEO turnover rates and TPS are robust to addressing the endogeneity associated with public status.

\section{Conclusion}

CEO turnover is a topic of considerable interest and ongoing debate. Because of their higher profile and the greater availability of data, public-firm CEOs' turnover and TPS generally have received most of the interest in the extant literature. Noting the importance of private firms in the economy and the potential to gain new insights into the drivers of CEO turnover in general, we study CEO turnover in large U.S. private firms. We further argue that by exploiting the differences between public and private firms, we can gain insights into the factors driving public-firm CEO turnover.

We begin with the finding that public-firm CEOs experience more turnover and more performance-sensitive turnover than do private-firm CEOs. We explore the impact of a range of differences between public and private firms and conclude that one contributor to this difference appears to be public-firm investor myopia. Our evidence suggests that public-firm CEOs are sometimes fired suboptimally early, consistent with the model by Fisman et al. (2014), and documents an additional cost of investor myopia as modeled by Stein (1989). The threat of early dismissal also helps explain why we observe the myopic managerial behavior documented by Bushee (1998), Gao et al. (2013), and Asker et al. (2015). Finally, our results are also consistent with Coles et al. (2003), who argue that great TPS is not a common feature of private firms' incentive-alignment mechanisms.

\section{Appendix. Variable Definitions}

ACCRUAL: |Earnings before extraordinary items and discontinued operations - Operating cash flow from continuing operations|/ Total assets.

BOARD_INDEPENDENCE: The fraction of outside directors on a board. Board information for private firms is hand collected from annual reports and proxy statements. Board information for public firms is obtained from the Investor Responsibility Research Center (IRRC) and BoardEx.

CEO_AGE: Age of the CEO.

CEO_OWNERSHIP: The stock ownership held by a CEO. For public firms, we first collect the CEO ownership data from ExecuComp, Corporate Library, and IRRC; for firms not covered in those databases, we hand-collect the CEO ownership data from annual reports and proxy statements. For private firms, we hand-collect the CEO ownership data from annual reports and proxy statements.

CEO_PAY: CEO annual compensation following Gao and Li (2015).

CEO_TENURE: The number of years that a CEO has held his or her position.

CEO_TURNOVER: An indicator variable that takes a value of 1 if a CEO is replaced in a year, and 0 otherwise.

\footnotetext{
${ }^{13}$ In Table IA4 in the Internet Appendix, we repeat the second-stage regression in column 2 of Table 7 after removing CEOs who are close to retirement (with age $\geq 63$ ), CEOs who are founders, and CEOs with ownership $\geq 10 \%$. We continue to show that there are significantly higher turnover rates and greater CEO TPS in public firms compared with private firms.
} 
CF_VOLATILITY: The standard deviation of industry-median-adjusted quarterly operating cash flows over the previous 8 quarters.

CONTEMPORANEOUS_ROA: Return on assets in year $t$, computed by Capital IQ as EBIT/total assets.

CONTEMPORANEOUS_SALES_GROWTH: Sales $(t)$ /sales $(t-1)-1$.

CONTROL_ADJUSTED_ROA: For each CEO turnover event firm, we first identify a group of firms with no CEO turnover in the same Fama and French (1997) 48 industries whose sales in the turnover year (year 0) are within $[50 \%, 150 \%]$ of the sales of the CEO turnover event firm. Among them, we then pick the control firm with the closest 2-year cumulative ROA in year -1 and year 0 . The control-adjusted ROA of each CEO turnover event firm is computed by subtracting the ROA of its control firm.

CONTROL_ADJUSTED_SALES_GROWTH: For each CEO turnover event firm, we first identify a group of firms with no CEO turnover in the same Fama and French (1997) 48 industries whose sales in the turnover year (year 0) are within [50\%, 150\%] of the sales of the CEO turnover event firm. Among them, we then pick the control firm with the closest 2-year cumulative sales growth in year -1 and year 0 . The controladjusted sales growth of each CEO turnover event firm is computed by subtracting the sales growth of its control firm.

FIRM_AGE: The number of years since a firm's incorporation.

FORCED_TURNOVER: An indicator variable that takes a value of 1 if there is a forced CEO turnover in a year, and 0 otherwise. Following Parrino (1997), we classify a CEO turnover as forced if the press reports that the CEO is fired or forced out or retires or resigns due to pressure. Departures for CEOs younger than 60 years old are also classified as forced if either the press does not report the reason as death, poor health, or the acceptance of another position (including the chairmanship of the board) or the press reports that the CEO is retiring but does not announce the retirement at least 6 months before the turnover.

FOUNDER: An indicator variable that takes a value of 1 if a CEO is a firm's founder, and 0 otherwise.

HIGH_BOARD_INDEPENDENCE: An indicator variable that takes a value of 1 if the fraction of outside directors on a board is greater than the sample median, and 0 otherwise. Board information for private firms is hand collected from annual reports and proxy statements. Board information for public firms is obtained from IRRC and BoardEx.

HIGH_CEO_OWNERSHIP: An indicator variable that takes a value of 1 if CEO_OWNERSHIP is greater than 5\%, and 0 otherwise.

HIGH_CEO_PAY: An indicator variable that takes a value of 1 if CEO annual compensation is greater than the sample median, and 0 otherwise.

HIGH_CF_VOLATILITY: An indicator variable that takes a value of 1 if CF_VOLATILITY is greater than the sample median, and 0 otherwise.

HIGH_TOP5_OWNERSHIP: An indicator variable that takes a value of 1 if the ownership held by the 5 largest outside shareholders is greater than the sample median, and 0 otherwise.

LAGGED_SALES_GROWTH: Sales $(t-1) /$ sales $(t-2)-1$.

LAGGED_ROA: Return on assets in year $t-1$, computed by Capital IQ as EBIT/total assets.

LEVERAGE: Total debt/total assets.

NUMBER_OF_EMPLOYEES: The number of a firm's employees. 
NUMBER_OF_FIRMS_IN_THE_INDUSTRY: For public (private) firms, the number of public (private) firms in the same industry.

NUMBER_OF_FIRMS_IN_THE_STATE: For public (private) firms, the number of public (private) firms in the same state.

PRIVATE_TURNOVER: An indicator variable that takes a value of 1 if a private firm experiences CEO turnover in a year, and 0 otherwise.

PUBLIC: An indicator variable that takes a value of 1 if a firm is a public firm in a year, and 0 otherwise.

PUBLIC_TURNOVER: An indicator variable that takes a value of 1 if a public firm experiences CEO turnover in a year, and 0 otherwise.

ROA: The 2-year cumulative return on assets, computed by Capital IQ as EBIT/total assets.

SALES_GROWTH: The 2-year cumulative sales growth.

SHORT_TERM_PUBLIC: For each firm-year, we first compute the short-term ownership as the difference between ownership by transient institutional investors and ownership by dedicated institutional investors. The indicator variable takes a value of 1 if a public firm's short-term ownership is in the top quartile of all public firms, and 0 otherwise.

SHORT_TERM_PUBLIC_TURNOVER: An indicator variable that takes a value of 1 if a short-term public firm experiences CEO turnover in a year, and 0 otherwise.

STATE_LEVEL_STOCK_ MARKET_PARTICIPATION_RATE: The number of households that make a non-zero stock investment normalized by the total number of households in a given state in 1984 .

STOCK_RETURN: The 2-year cumulative stock return.

TOP5_OWNERSHIP: The percentage ownership held by the 5 largest outside shareholders.

VOLUNTARY_TURNOVER: An indicator variable that takes a value of 1 if there is a voluntary CEO turnover in a year, and 0 otherwise.

$\triangle$ ROA: Average of ROA in year $t+1$ to $t+3-\mathrm{ROA}$ in year $t$.

$\triangle$ SALES_GROWTH: Average of sales growth in year $t+1$ to $t+3-$ sales growth in year $t$.

\section{References}

Ai, C., and E. C. Norton. "Interaction Terms in Logit and Probit Models." Economics Letters, 80 (2003), 123-129.

Angrist, J. "Estimation of Limited Dependent Variable Models with Dummy Endogenous Regressors: Simple Strategies for Empirical Practice.” Journal of Business and Economic Statistics, 19 (2001), $2-16$.

Angrist, J., and A. Krueger. "Instrumental Variables and the Search for Identification: From Supply and Demand to Natural Experiments." Journal of Economic Perspectives, 15 (2001), 69-85.

Asker, J.; J. Farre-Mensa; and A. Ljungqvist. "Corporate Investment and Stock Market Listing: A Puzzle?" Review of Financial Studies, 28 (2015), 342-390.

Barber, B. M., and J. D. Lyon. "Detecting Abnormal Operating Performance: The Empirical Power and Specification of Test Statistics." Journal of Financial Economics, 41 (1996), 359-399.

Bhide, A. "The Hidden Cost of Stock Market Liquidity." Journal of Financial Economics, 34 (1993), $34-51$.

Black, F., and M. Scholes. "The Pricing of Options and Corporate Liabilities." Journal of Political Economy, 81 (1973), 637-654.

Boone, A. L., and V. I. Ivanov. "Bankruptcy Spillover Effects on Strategic Alliance Partners." Journal of Financial Economics, 103 (2012), 551-569.

Borokhovich, K.; R. Parrino; and T. Trapani. "Outside Directors and CEO Selection.” Journal of Financial and Quantitative Analysis, 31 (1996), 337-355.

Brochet, F.; M. Loumioti; and G. Serafeim. "Speaking of the Short-Term: Disclosure Horizon and Corporate Myopia." Review of Accounting Studies, 20 (2015), 1122-1163. 
Brown, J.; Z. Ivkovic; P. Smith; and S. Weisbenner. "Neighbors Matter: Causal Community Effects and Stock Market Participation.” Journal of Finance, 63 (2008), 1509-1531.

Bushee, B. J. "The Influence of Institutional Investors on Myopic R\&D Investment Behavior." Accounting Review, 73 (1998), 305-333.

Bushee, B. J. "Do Institutional Investors Prefer Near-Term Earnings over Long-Run Value?" Contemporary Accounting Research, 18 (2001), 207-246.

Campello, M.; J. R. Graham; and C. R. Harvey. "The Real Effects of Financial Constraints: Evidence from a Financial Crisis.” Journal of Financial Economics, 97 (2010), 470-487.

Chow, G. C. "Tests of Equality Between Sets of Coefficients in Two Linear Regressions." Econometrica, 28 (1960), 591-605.

Coles, J.; M. Lemmon; and L. Naveen. "A Comparison of Profitability and CEO Turnover Sensitivity in Large Private and Public Firms.” Working Paper, Arizona State University (2003).

Cornelli, F., and O. Karakaş. "CEO Turnover in LBOs: The Role of Boards.” Working Paper, London Business School (2015).

Cornelli, F.; Z. Kominek; and A. Ljungqvist. “Monitoring Managers: Does It Matter?” Journal of Finance, 68 (2013), 431-481.

Coughlan, A., and R. Schmidt. "Executive Compensation, Management Turnover, and Firm Performance: An Empirical Investigation.” Journal of Accounting and Economics, 7 (1985), 43-66.

Coval, J., and T. Moskowitz. "Home Bias at Home: Local Equity Preference in Domestic Portfolios." Journal of Finance, 54 (1999), 1-39.

Denis, D. J.; D. K. Denis; and A. Sarin. “Ownership Structure and Top Executive Turnover.” Journal of Financial Economics, 45 (1997), 193-222.

Derrien, F.; A. Kecskés; and D. Thesmar. "Investor Horizons and Corporate Policies.” Journal of Financial and Quantitative Analysis, 48 (2013), 1755-1780.

Fama, E., and K. French. "Industry Costs of Capital." Journal of Financial Economics, 43 (1997), $153-193$.

Fisman, R.; R. Khurana; M. Rhodes-Kropf; and S. Yim. "Governance and CEO Turnover: Do Something or Do the Right Thing?” Management Science, 60 (2014), 319-337.

Gao, H.; J. Harford; and K. Li. "Determinants of Corporate Cash Policy: Insights from Private Firms." Journal of Financial Economics, 109 (2013), 623-639.

Gao, H., and K. Li. "A Comparison of CEO Pay-Performance Sensitivity in Privately-Held and Public Firms." Journal of Corporate Finance, 35 (2015), 370-388.

Guo, L., and R. Masulis. "Information Quality and CEO Turnover." Working Paper, University of New South Wales (2012).

Harford, J. “Takeover Bids and Target Directors' Incentives: The Impact of a Bid on Directors' Wealth and Board Seats." Journal of Financial Economics, 69 (2003), 51-83.

Huson, M. R.; P. H. Malatesta; and R. Parrino. "Managerial Succession and Firm Performance." Journal of Financial Economics, 74 (2004), 237-275.

Huson, M. R.; R. Parrino; and L. T. Starks. "Internal Monitoring Mechanisms and CEO Turnover: A Long-Term Perspective.” Journal of Finance, 56 (2001), 2265-2297.

Jenter, D., and F. Kanaan. "CEO Turnover and Relative Performance Evaluation.” Journal of Finance, 70 (2015), 2155-2184.

Jenter, D., and K. Lewellen. "Performance-Induced CEO Turnover.” Working Paper, Stanford University (2014).

Kahn, C., and A. Winton. "Ownership Structure, Speculation, and Shareholder Intervention.” Journal of Finance, 53 (1998), 99-129.

Kaplan, S. N., and B. A. Minton. "How Has CEO Turnover Changed?" International Review of Finance, 12 (2012), 57-87.

Kaplan, S. N.; B. Sensoy; and P. Strömberg. "Should Investors Bet on the Jockey or the Horse? Evidence from the Evolution of Firms from Early Business Plans to Public Companies." Journal of Finance, 64 (2009), 75-115.

Ke, B.; K. Petroni; and A. Safieddine. "Ownership Concentration and Sensitivity of Executive Pay to Accounting Performance Measures: Evidence from Publicly and Privately-Held Insurance Companies.” Journal of Accounting and Economics, 28 (1999), 185-209.

Kolasinski, A. C., and A. F. Siegel. "On the Economic Meaning of Interaction Term Coefficients in Non-Linear Binary Response Regression Models.” Working Paper, Texas A\&M University (2010).

Lel, U.; D. Miller; and N. Reisel. "Differences in Agency Problems between Public and Private Firms: Evidence from Top Management Turnover.” Working Paper, Virginia Tech (2014).

Parrino, R. "CEO Turnover and Outside Succession: A Cross-Sectional Analysis." Journal of Financial Economics, 46 (1997), 165-197.

Parrino, R.; R. W. Sias; and L. T. Starks. "Voting with Their Feet: Institutional Ownership Changes around Forced CEO Turnover.” Journal of Financial Economics, 68 (2003), 3-46. 
Stein, J. C. "Takeover Threats and Managerial Myopia." Journal of Political Economy, 96 (1988), $61-80$.

Stein, J. C. "Efficient Capital Markets, Inefficient Firms: A Model of Myopic Corporate Behavior." Quarterly Journal of Economics, 104 (1989), 655-669.

Taylor, L. A. "Why Are CEOs Rarely Fired? Evidence from Structural Estimation." Journal of Finance, 65 (2010), 2051-2087.

Warner, J. B.; R. L. Watts; and K. H. Wruck. "Stock Prices and Top Management Changes.” Journal of Financial Economics, 20 (1988), 461-492.

Weisbach, M. S. "Outside Directors and CEO Turnover." Journal of Financial Economics, 20 (1988), 431-460. 